\title{
Grey Strategies Interaction Model
}

\begin{tabular}{|r|l|}
\hline Journal: & Journal of Strategy and Management \\
\hline Manuscript ID & JSMA-06-2018-0055.R4 \\
\hline Manuscript Type: & Research Paper \\
\hline Keywords: & $\begin{array}{l}\text { SWOT analysis, Strategies interaction model (SIM), Grey systems, } \\
\text { Shannon's Entropy }\end{array}$ \\
\hline \multicolumn{2}{|l}{} \\
\hline
\end{tabular}

SCHOLARONE ${ }^{\text {Im }}$

Manuscripts 


\begin{abstract}
Purpose - This paper aims to implement the strategies selection process in a proposed formulated mathematical framework to prioritize selected strategies with the interaction of other groups of strategies, known as the strategies interaction model (SIM).

Design/methodology/approach - SWOT analysis is a popular useful strategic planning tool, which analyzes organizations internal and external factors. The traditional SWOT procedure lists internal and external factors and derives four groups of strategies based on the organization's strategic position. SWOT is easy to use as a business analyzing tool, while it is not competent enough for strategic formulation. With the emergence of the economy's vicissitudes, undulations in the markets and multiple changes, and various variables in the industrial competitive environment, selection of the organization strategies confront uncertainty in decision-making. The SIM framework presents a solution to select alternative strategies for organizations in unpredictable situations.
\end{abstract}

Findings - The findings show that SIM is a reliable approach to evaluate, select and rank organization' strategies. SIM proposes alternative strategies due to the uncertainty of the organization' environment with respect to the four strategic positions. The SIM' proposed ranking process is in accordance with the highest impact of each strategy on each other. Furthermore, it possesses advantages of AHP, ANP and other applied MCDM techniques in SWOT analysis.

Practical implications - In this paper SIM is applied within a dairy company located in the north of Iran.

Originality/value - SIM has the advantages of the classic SWOT and fills the gaps of MCDM methods application in the SWOT analysis. Moreover, it provides a formulated algorithm for the organizations to face the uncertainty of the environment. SIM philosophy can be widely used in the decision and managerial implications.

Keywords: SWOT analysis; Strategies interaction model (SIM); Grey systems; Shannon's Entropy

\title{
1. Introduction
}

Strategic planning is a management tool that enables employees to canalize the organization's targets and helps to identify long-term goals, current status, and future plans of the organization via identifying root causes of problems at all levels of the entire organization (toklu, et al.2016). Franham (1999) set out three stages in the strategic management process: strategy formulation, strategy implementation, and strategy evaluation. As he stated, strategy formulation includes developing a business mission; identifying an organization's external opportunities and threats; determining internal strengths and weaknesses; establishing long-term objectives; generating alternative strategies, and choosing particular strategies to pursue. Strategy formulation also includes 'deciding what new businesses to enter, what businesses to abandon, how to appropriate resources, whether to expand operations or diversify, whether to enter international markets, whether to merge or form a joint venture and how to avoid a hostile takeover'.

The first step of the strategic planning process is to define the organization's strength and weaknesses as internal factors and the specification of an organization's opportunities and environmental threats as the organization's external factors. For analyzing and identifying internal and external factors, organizations use the SWOT matrix. By determination of these factors, the developed strategies may be built on the strengths, or they eliminate the weaknesses, exploit the opportunities, or counter the threats (Wang et al.,2014; Zhang and Feng, 2013; Dyson,2004).

Learned (1969) first described SWOT analysis. SWOT analysis has been grown as a key tool for addressing complex strategic situations by reducing the quantity of information to improve decision-making. SWOT analysis is one of the most recognized and established strategic formulation techniques. It has been used in various fields of the current and emerging issues (Syazwan and Bakar, 2014; He and Liao,2012; Helms et al., 2011; Panagiotou, 2003; Glaister and Falshaw,1999). SWOT analysis can be utilized in a wide range of topics. For instance, Yan et al. (2015) proposed a national strategic planning framework for land consolidation, with a focus on the clarification of internal strength and weakness strategies and external opportunity and threat strategies involved in the land consolidation process. In an analytical framework, Fertel et al. (2013) used SWOT analysis on the themes of energy security, energy efficiency, technology, and innovation.

With defying the organization's mission and vision, the original SWOT analysis starts with identification of internal factors (strengths and weaknesses) and external factors (opportunities and threats). The evaluation of the aforementioned factors is performed in the IFE (internal factors evaluation) and EFE (external factors evaluation) matrices. The evaluation specifies the organization's strategic position. SWOT matrix includes four strategic groups. These groups are the result of four combination processes as: strengths and opportunities as aggressive strategies ( $S O$-maxi- maxi), strengths and threats as competitive strategies ( $S T$-maxi-mini), weaknesses and opportunities as conservative strategies (WO maxi-mini), and weaknesses and threats as defensive strategies (WT -mini-mini). Aggressive (offensive) strategies represent maximum exploitation of the synergy effect present between the organization's strengths and opportunities generated by the environment (Krzysztof, 2007). Competitive strategies refer to prevailing opportunities in the environment and denote domination of the weaknesses over strengths; this group of strategies reduces weaknesses with the application of opportunities. Conservative strategies attempt to overcome the threats with utilization of the opportunities as external factors. The survival arena is in the defensive position. Without any opportunities or strength factors, the package of these strategies leads organizations to minimize threats and weaknesses. The resultant of IFE and EFE matrices determines organization position within the above-mentioned four classes. Indeed, in a typical SWOT analysis process, strategic position, and selected strategies of the organization are inextricably bound together.

Strategy formulation is based on the derived strategic position from SWOT analysis process. As a decision-making stage, the final step of the original SWOT analysis, the strategies are selected through quantitative strategic planning (QSPM). In fact, the concept of QSPM matrix is based on the relation matrix, which evaluates and prioritizes the selected strategies through internal and external factors. As discussed earlier, QSPM only evaluates the selected strategies, while it ignores other groups of strategies, regardless of their importance or environmental uncertainties. Therefore, the output of QSPM is a crisp answer that only embraces a certain world whereby it technically avoids uncertainty or other strategic positions. 
In the real world, the impacts of unpredictable conditions on businesses are an integral part of businesses life cycle, where there are many variables hidden behind factors which seem completely irrelevant to the business, but they are not. In SWOT analysis, the derived strategies from the typical procedures do not follow the vagueness of an organization's environment such as market, political, economic and environmental conditions or social and technical conditions (PEST). In the business, for the strategic decision making of the progress, conservation or survival, a clear and direct answer is essential. This answer which is built on the internal factors encompasses all environmental factors. Hence, to address these problems a framework is needed that contains the possible strategic positions, elucidates environmental uncertainties, and offers alternative strategies. In this paper, we proposed an algorithm called strategies interaction model (SIM); SIM data structure evaluates interactions of strategies of each strategic position. Moreover, SIM suggests alternative strategies for selection for each organization strategic position. To eliminate vagueness, subjectivity, and imprecision with the application, we developed a grey form of SIM. With the proposition of SIM, this paper aims to solve the following problems:

1. Strategic position ignorance in the hybrid methodologies of MCDM and SWOT.

2. Lack of an integrated model for the selection of an organization strategies and also alternative strategies in accordance with the organization strategic position.

3. In respect of the shared resources for implementation and operation of strategies, there is no framework to assess the interaction of strategies due to their budget requirement.

4. Lack of a formulated framework to support the assessment of the interaction of possible unselected strategies on the prioritization of the main selected strategies.

The paper is structured as follows: various SWOT applications, and also the application of MADAM methodologies in SWOT analysis has been described in section 2. In section 3, the methodologies and concepts which are utilized in the proposed framework have been defined. SIM and its steps have been demonstrated in section 4 . The fifth section is devoted to the case study, and SIM application and results. The results discussion of SIM and the conclusion of the research have been located in section 6. Finally, future work are exposed in section 7.

\section{Literature review}

In this section, we provide a literature review of SWOT applications, then MCDM applications inSWOT analysis have been described. There are four conventional strategic tools including SWOT analysis, PESTEL (Yüksel, 2012), gap analysis (Brown and Swartz, 1989), and five forces analysis (Grundy, 2006) used by organizations to conduct analyses and make strategic decisions. Amongst strategic tools, SWOT is the most popular strategic management tool. As a strategic tool, the concept of SWOT analysis utilized in the various fields of research. The following table shows the recent application of SWOT in research and studies.

Table 1

Literature review of application of SWOT

\begin{tabular}{|c|c|c|c|c|c|c|c|}
\hline Topic & Author & Year & Focus & Topic & Author & Year & Focus \\
\hline \multirow[t]{2}{*}{$\begin{array}{c}\text { Environment and } \\
\text { energy }\end{array}$} & $\begin{array}{c}\text { Szulecka } \\
\text { and Zalazar }\end{array}$ & 2017 & $\begin{array}{l}\text { With an AHP-SWOT analysis combined } \\
\text { method, they found } 36 \text { factors that } \\
\text { influence plantation establishment in } \\
\text { rainy forest of Paraguay }\end{array}$ & logistic & $\begin{array}{c}\text { Tavana et } \\
\text { al }\end{array}$ & 2016 & $\begin{array}{l}\text { In a fuzzy environment, with a hybrid } \\
\text { method of Fuzzy AHP and SWOT } \\
\text { analysis, this study evaluated strategic } \\
\text { factor in an outsourcing reverse logistics. }\end{array}$ \\
\hline & Shi & 2016 & $\begin{array}{l}\text { This study used SWOT to review } \\
\text { internal and external factors of green } \\
\text { energy using in Association of Southeast } \\
\text { Asian Nations (ASEAN) }\end{array}$ & & & & \\
\hline \multirow[t]{4}{*}{$\begin{array}{l}\text { Agriculture and } \\
\text { foods }\end{array}$} & $\begin{array}{l}\text { Syazwan \& } \\
\text { Bakar }\end{array}$ & 2014 & $\begin{array}{l}\text { To identify SWOT in the Halal logistics } \\
\text { environment, this study focused Halal } \\
\text { logistics industry in Malaysia. }\end{array}$ & $\begin{array}{l}\text { supply chain } \\
\text { and services }\end{array}$ & $\begin{array}{c}\text { Verraes et } \\
\text { al }\end{array}$ & 2015 & $\begin{array}{l}\text { With a comparative analysis of } \\
\text { microbiological quality and safety } \\
\text { aspects, this research compared short } \\
\text { food supply chain and conventional food } \\
\text { supply chain in Belgium through SWOT } \\
\text { analysis. }\end{array}$ \\
\hline & Suh & 2014 & $\begin{array}{l}\text { With using expert elicitation method, } \\
\text { this study used SWOT analysis for case } \\
\text { of the integrated rice-duck farming in } \\
\text { South Korea, Malaysia and Vietnam. }\end{array}$ & & 冫 & & \\
\hline & Çelik et al & 2013 & $\begin{array}{l}\text { This study deal with SWOT analysis to } \\
\text { find strengths and weaknesses, and } \\
\text { threats and opportunities of the Turkish } \\
\text { fishery sector through a workshop with } \\
\text { the fishery companies. }\end{array}$ & health & $\begin{array}{l}\text { Van Durme } \\
\text { et al }\end{array}$ & 2014 & $\begin{array}{l}\text { This study proposed a methodoogy for } \\
\text { identification of problematic domains in } \\
\text { the health system for people living with } \\
\text { chronic conditions by SWOT analysis } \\
\text { through thematic analysis of the } \\
\text { transcripts. }\end{array}$ \\
\hline & & & & & Kuo et al & 2011 & $\begin{array}{l}\text { This research evaluated the feasibility of } \\
\text { adopting cloud computing model in } \\
\text { healthcare by SWOT analysis. }\end{array}$ \\
\hline Production & Li et al & 2016 & $\begin{array}{l}\text { With and data collection from literature } \\
\text { review, prefabrication-related } \\
\text { regulations, interviews with experts, and } \\
\text { government reports, this study deal with } \\
\text { SWOT analysis to facilitate a more in- } \\
\text { depth understanding of the management } \\
\text { of prefabrication housing production } \\
\text { development status in housing }\end{array}$ & & & & \\
\hline
\end{tabular}


production in Hong Kong.

Nagara et 2015 This paper applies SWOT (strengths, analysis to examine the suitability of virtual water trading, desalination, groundwater extraction and wastewater reuse as alternative water solutions to alleviate water scarcity. weaknesses, opportunities and threats)

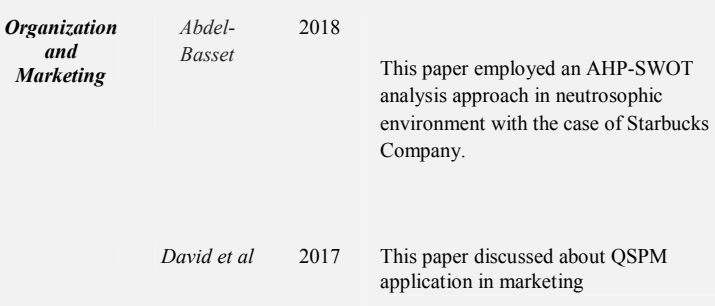

Decision making is the important part of the SWOT analysis process which has good capability to integrate and combine with MCDM methods. In general, MCDM refers to multi-attributes decision-making (MADM) and multi-objective decision making (MODM). Widely, multiple criteria decision making (MCDM) methods have been employed in SWOT to solve strategic decision-making problem. These studies have transferred SWOT procedures into MCDM algorithms and made various solution frameworks with the proposed hybrid models. In this section, the application of TOPSIS , AHP , ANP , VIKOR , Entropy, GRA, DEMATEL , DEA, and the Goal Programming as the most popular MCDM methods in SWOT analysis have been described. Review of application of the aforementioned techniques is expressed in (Table 2) in the specific areas.

Table 2

Review of the literature. Combination of MCDM methodologies with SWOT analysis




MA, ZHOU and WANG

Ghorbani, Bahrami and Arabzad

DEMATEL Nikjoo and Saeedpoor

Saeedpoor, Kazzazi, Kashani and Nikjoo

Yang-tian, Wei-zhong, Yi-feng,, Hong-sheng and Center

$D E A$

Linear

Programming
ABZARI, BALOUEI, KHAZAEI, and POOR

Amin, Razmi and Zhang

Ghorbani, Arabzad and Bahrami

Ghorbani, Bahrami and Arabzad

\begin{tabular}{|c|c|}
\hline 2009 & Traffic \\
\hline 2012 & Supply Chain \\
\hline 2014 & Insurance industry (Iran) \\
\hline 2012 & A combination of Grey theory and DEMATEL \\
\hline 2013 & lightning protection and disaster mitigation situation \\
\hline 2013 & Governmental \\
\hline 2011 & Supply chain \\
\hline 2012 & Supply Chain \\
\hline 2012 & Supply Chain \\
\hline
\end{tabular}

With evaluation of strategies as the alternative against internal and external factors as the criteria, TOPSIS plays the role of decision-making tool in SWOT analysis. Due to the hierarchy structure of SWOT, a lot of research have dealt with AHP and ANP in SWOT analysis process (see Table 2). Integration process of AHP (or ANP) with SWOT analysis in a hierarchy structure is as follows: SWOT factors (Weaknesses, Strengths, Threats, and Opportunities) as criteria, SWOT sub-factors as the sub-criteria and the strategies as alternatives are placed in descending order of hierarchy structure (Shahabi et al, 2014). In this process, at first all strategies (ST, SO, WT and WO) are determined in SWOT matrix, then they prioritize as the output of AHP or ANP process. Like combination of TOPSIS method and SWOT analysis, there is no clear paradigm for attention to the organization strategic position and the above approaches ignore organization strategic position practically, while it is the first factor for evaluation of strategies.

For operation and implementation of the selected strategies, organizations have to allocate the resources. Due to the shared resources, strategies affect each other. Therefore, according to the strategic position of the organization, that strategy which has the highest impact on other strategies needs more resources than the others do. Hence, as long as SWOT procedure is based on scores and importance of internal and external factors, the strategy with the highest effect on other strategies must reach the higher rank because the basis of interaction is indirectly according to the importance. Thus, in one hand, there are algorithms, which rank strategies due to an organization's internal and external factors and suggest the selected strategies without consideration of the organization's strategic position. On the other hand, there is a missing framework for the calculation of interaction between strategies. As a result of these shortfalls, a comprehensive framework is needed that attends an organization's strategic position and also embraces interactions.

\section{Method and Tools}

The original SWOT analysis procedure does not offer extra strategies to cover all strategic positions . Extra strategies are the alternatives of the main output of the decision-making part of SWOT analysis to propose a plan for actions due to other strategic positions. Likewise, the original SWOT procedure does not support a framework for the assessment of the interaction of possible unselected strategies on the ranking of the main selected strategies. The nature of SWOT analysis is the decision making for "what strategy is more suitable for the current strategic position?", but by integration with MCDM methods, it ignores other strategic positions of the organization. Turning to the description, we proposed the SIM algorithm. The basis of SIM is the calculation of interaction between each strategy of the strategic positions. The key of SIM is the value of interaction $(V I)$. In the real world applications and decision-making, the vagueness increases due to inappropriate human judgements and imprecise information (Çelikbilek and Tüysüz, 2016; Tseng, 2009), and SIM data structure and algorithm basics are based on decision-maker's (DM) decisions. As the human judgments, DM(s) decisions face with uncertainty, incomplete information, vagueness, partial ignorance, and nonobtainable information. Thus, to handle uncertainty, all SIM functions deal with the grey numbers and the grey operations. Grey systems theory was first introduced by Professor Deng $(1982 ; 1985)$. Grey concepts have been developed to apply in many subjects (Deng. 1989; 1990). Like fuzzy set theory (Zadeh, 1965), grey systems theory is an effective tool to enable integration of uncertainty and ambiguity into the evaluation process (Çelikbilek and Tüysüz, 2016).

3.1. Grey Operations

The basic element of grey systems theory is the grey numbers which describe vagueness and uncertain information. The relationship between the grey number and grey systems theory is analogous with the relationship between a fuzzy number and fuzzy mathematics (Xie and Liu, 2010). The exact value of a grey $(\otimes G)$ number is unknown, while it lies between two bounds of a numerical interval. Hence, the grey number is defined as a numerical interval with two known upper and lower bounds as $(\otimes G=[\underline{G}, \bar{G}])$. Such a method supplements the expression of system uncertainties whenever the probability density and membership functions cannot be fully identified (Memon, et al. 2015). Following equations Eq.(1-10) address the grey number operations:

If $\otimes G_{1}=\left[\underline{G_{1}}, \overline{G_{1}}\right], \otimes G_{2}=\left[\underline{G_{2}}, \overline{G_{2}}\right]$ then $\overline{G_{1}}>\underline{G_{1}}$ and $\overline{G_{2}}>\underline{G_{2}}$ therefore

1) $-\otimes G_{1}=\left[\overline{-G_{1}}, \underline{-G_{1}}\right]$

2) Grey number addition:

$\otimes G_{1}+\otimes G_{2}=\left[\underline{G_{1}}+\underline{G_{2}}, \overline{G_{1}}+\overline{G_{2}}\right]$

3) Grey number subtraction:

4) Grey number multiplication:

$\otimes G_{1} \times \otimes G_{2}=\left[\min \left\{\underline{G_{1}} \underline{G_{2}}, \underline{G_{1}} \overline{G_{2}}, \overline{G_{1}} \underline{G_{2}}, \overline{G_{1}} \overline{G_{2}}\right\}, \max \left\{\underline{G_{1}} \underline{G_{2}}, \underline{G_{1}} \overline{G_{2}}, \overline{G_{1}} \underline{G_{2}}, \overline{G_{1}} \overline{G_{2}}\right\}\right]$

$r \times \otimes G_{1}=\left[r \underline{G_{1}}, r \overline{G_{1}}\right]$

5) Grey number division

6) $\otimes G_{1} / \otimes G_{2}=\left[\underline{G_{1}}, \overline{G_{1}}\right] \times\left[\underline{\frac{1}{G_{2}}}, \frac{1}{\overline{G_{2}}}\right]=\left[\underline{G_{1}}, \overline{G_{1}}\right] \times\left[\underline{G_{2}^{-1}}, \overline{G_{2}^{-1}}\right]=\left[\min \left\{\underline{G_{1}} \underline{G_{2}^{-1}}, \underline{G_{1}} \overline{G_{2}^{-1}}, \overline{G_{1}} \underline{G_{2}^{-1}}, \overline{G_{1}} \overline{G_{2}^{-1}}\right\}, \max \left\{\underline{G_{1}} \underline{G_{2}^{-1}}, \underline{G_{1}} \overline{G_{2}^{-1}}, \overline{G_{1}} \underline{G_{2}^{-1}}, \overline{G_{1}} \overline{G_{2}^{-1}}\right\}\right]$ (7)

7) $\frac{\otimes G_{1}}{a}=\left[\frac{G_{1}}{\bar{a}}, \frac{\overline{G_{1}}}{a}\right]$ $\frac{a}{\overline{\otimes G_{1}}}=\left[\frac{a}{G_{1}}, \frac{a}{\overline{G_{1}}}\right]$

8) The possibility degree of $\otimes G_{1} \leq \otimes G_{2}$ : 


$$
p\left\{\otimes G_{1} \leq \otimes G_{2}\right\}=\frac{\max \left(0, L^{*}-\max \left(0, \underline{G_{1}}-\overline{G_{2}}\right)\right)}{L^{*}}, \text { Where } L^{*}=L\left(\otimes G_{1}\right)+L\left(\otimes G_{2}\right)
$$

The grey linguistic variables utilized for the rating attributes are: very poor (abbrivated to VP), poor (P), medium Poor (MP), fair (F), medium good (MG), good (G), and very good (VG), where their corresponding grey values are $[0,1],[1,3],[3,4],[4,5],[5,6],[6,9]$, and $[9,10]$ respectively. On the flip side, $[0.0,0.1],[0.1,0.3],[0.3,0.4],[0.4,0.5],[0.5,0.6],[0.6,0.9],[0.9,1.0]$ are the grey values assigned for the very low $(\mathrm{VL})$, low $(\mathrm{L})$, moderate low $(\mathrm{ML})$, moderate $(\mathrm{M})$, moderate high $(\mathrm{MH})$, high $(\mathrm{H})$, very high $(\mathrm{VH})$ as the weighting attributes linguistic variables.

3.2. Shannon's Entropy

One of the major results of information theory is the Shannon's entropy (Laurenza et al.2012; Shannon.2001). This method is using to weight the criteria. The grey entropy can be found in Eq. $(11 ; 12)$ in accordance to (Sachdeva et al., 2009; Das et al., 2014) where $\left(e_{\underline{G}_{j}^{\prime}}\right.$ ande $\left.e_{\bar{G}_{j}^{\prime}}\right)$ expresses entropy of each criteria, and $\left(w_{\underline{G}_{j}^{\prime}}\right.$ and $\left.w_{\bar{G}_{j}}\right)$ defines weight of each criteria in an interval.

$e_{\underline{G}_{j}^{\prime}}=-\frac{1}{\ln m} \sum_{i=1}^{m} \underline{G_{i j}^{\prime}} \ln \underline{G_{i j}^{\prime}}$

$e_{\bar{G}_{j}^{\prime}}=-\frac{1}{\ln m} \sum_{i=1}^{m} \bar{G}_{i j}^{\prime} \ln \bar{G}_{i j}^{\prime}$

With respect to Eq. $(11 ; 12)$, computation of weight of $J$ th criterion is as Eq. (13;14):

$w_{\underline{G}_{j}^{\prime}}=\left(1-e_{{\underline{G_{j}^{\prime}}}_{j}}\right) \cdot\left(\sum_{j=1}^{n}\left(1-e_{\underline{G}_{j}^{\prime}}\right)\right)^{-1}$

$w_{\bar{G}_{j}}=\left(1-e_{\bar{G}_{j}}\right) \cdot\left(\sum_{j=1}^{n}\left(1-e_{\bar{G}_{j}}\right)\right)^{-1}$

Where $\otimes G_{j}^{\prime}=\left[\underline{G}_{i j}^{\prime}, \bar{G}_{i j}^{\prime}\right]$ is normalized form of $\otimes G_{j}=\left[\underline{G}_{i j}, \bar{G}_{i j}\right]$

$\underline{G}_{i j}^{\prime}=\left(\sum_{i=1}^{m} \underline{G}_{i j}\right)^{-1} \cdot \underline{G}_{i j}$

$\bar{G}_{i j}^{\prime}=\left(\sum_{i=1}^{m} \bar{G}_{i j}\right)^{-1} \cdot \bar{G}_{i j}$

In another form of equation, let $\left(\lambda_{j}\right)$ be an added value such as DMs decisions, thus the Entropy formula will be as following equations: Let $\left(\lambda_{j}\right)$ be a crisp number therefore:

$w_{\underline{G}_{j}^{\prime}}=\lambda_{j}\left(1-e_{\underline{G}_{j}^{\prime}}\right) \cdot\left(\sum_{j=1}^{n} \lambda_{j}\left(1-e_{\underline{G}_{j}^{\prime}}\right)\right)^{-1}$

$w_{\bar{G}_{j}}=\lambda_{j}\left(1-e_{\bar{G}_{j}}\right) \cdot\left(\sum_{j=1}^{n} \lambda_{j}\left(1-e_{\bar{G}_{j}}\right)\right)^{-1}$

And if $\left(\lambda_{j}=\left[\lambda_{j}, \overline{\lambda_{j}}\right]\right)$ then

$w_{\underline{G}_{j}^{\prime}}=\underline{\lambda_{j}}\left(1-e_{\underline{G}_{j}^{\prime}}\right) \cdot\left(\sum_{j=1}^{n} \underline{\lambda}_{j}\left(1-e_{\underline{G}_{j}^{\prime}}\right)\right)^{-1}$

$w_{\bar{G}_{j}}=\bar{\lambda}_{j}\left(1-e_{\bar{G}_{j}}\right) \cdot\left(\sum_{j=1}^{n} \overline{\lambda_{j}}\left(1-e_{\bar{G}_{j}}\right)\right)^{-1}$

Entropy algorithm for the crisp numbers in certain environment is as follow as Eq. $(21,22)$ :

$e_{r_{j}}=-\frac{1}{\ln m} \sum_{i=1}^{m} r_{i j} \ln r_{i j}$

$w_{r_{j}}=\left(1-e_{r_{j}}\right) \cdot\left(\sum_{j=1}^{n}\left(1-e_{r_{j}}\right)\right)^{-1}$

The normalization process is in accordance to Eq.(23):

$r_{j}=\left(\sum_{i=1}^{m} x_{i j}\right)^{-1} \cdot x_{i j}$

3.3. Proposed Grey WPM (WPM-G)

For the ranking procedure, we proposed a transformed methodology which is called (WPM-G). WPM-G steps are in accordance with the weighted product model (WPM) process (Wang et al., 2010; Triantaphyllou, 2000). The proposed WPM-G equation is as follows (Eq.24) where $\otimes G=\left[\underline{G}_{i j}, \bar{G}_{i j}\right], \otimes G^{\prime}=\left[\underline{G}_{i j}^{\prime}, \bar{G}_{i j}^{\prime}\right]$, and with respect to the value of $P\left(G_{m}^{\prime}\right)$, alternatives arrange in their descending order, where $\otimes G_{j}^{\prime}=$ $\left[\underline{G}_{i j}^{\prime}, \bar{G}_{i j}^{\prime}\right]$ is normalized form of $\otimes G_{j}=\left[\underline{G}_{i j}, \bar{G}_{i j}\right]$ pursuant Eq.(15,16): 
$P\left(G_{m}^{\prime}\right)=\prod_{j=1}^{n}\left(G_{i j}+\bar{G}_{i j}\right)^{w_{j}}$

If $\left(w_{j}\right)$ be a grey number then

$P\left(G^{\prime}{ }_{m}\right)=\prod_{j=1}^{n}\left(\underline{G}_{i j}+\bar{G}_{i j}\right) \underline{\left(w_{j}+\overline{w_{j}}\right)}$

Where $w_{j}=\left[w_{j}, \overline{w_{j}}\right]$

\section{Strategies interaction model}

In the real world business, for strategic planning, there is no certain strategic position for an organization. In the external environment, there are variables that organizations are not capable to control them, such as competition rules, globalization, government policies, technological changes, natural forces, economic fluctuations, social and cultural forces, and demographic factors. These factors make the unpredictable impacts on the strategic decision making as well as the strategic decisions. It changes the previously approved strategies of a specific strategic position. For this reason, organizations have to face with every four strategic positions of SWOT matrix. Thus, in one hand, there is an algorithm, which proposes plans for actions in a certain strategic position, and on the other hand, there is no certain strategic position for organizations to make plans for their actions to achieve the long-term goals. Therefore, a comprehensive algorithm is needed to cover all strategic positions. As mentioned in (Table 2) TOPSIS, AHP and ANP are the most popular MCDM methods for integration with SWOT to make an algorithm to analyze SWOT for prioritization and selection of the best strategies, whereas these techniques do not consider organizations strategic positions. The core of SIM is to offer alternative strategies for each strategic position. Furthermore, SIM ranks strategies according to their interactions.

The workflow of SIM methodology procedure has been illustrated in Fig.1 to solve the mentioned problems (see introduction section). In the proposed procedure, there are two main areas: the evaluation, and the selection. The evaluation and all computation activities will be progressed in the evaluation area and the results will be processed in the selection area.

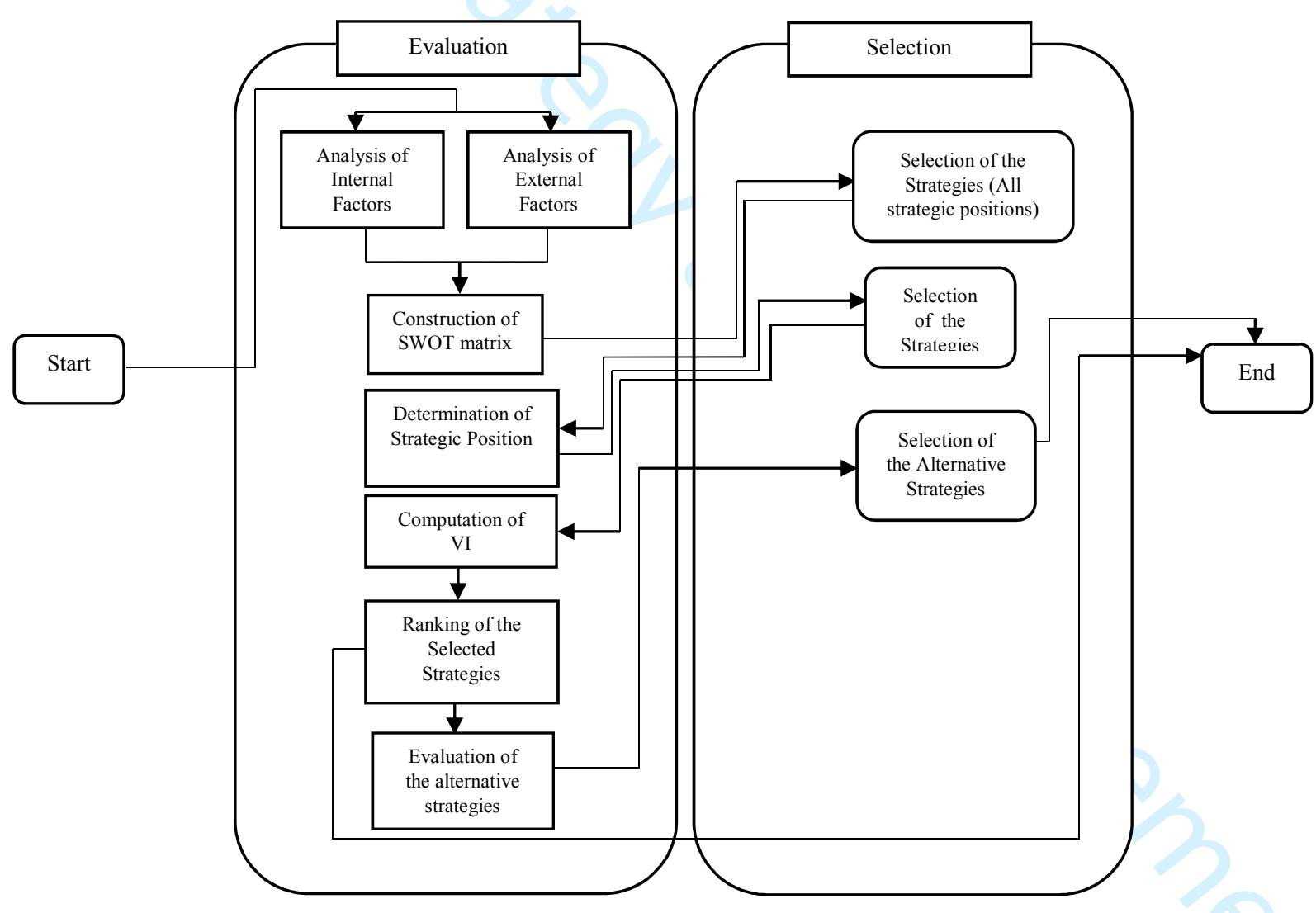

Fig 1. The Proposed methodology procedure workflow of SIM

The procedure includes five phases as they are mentioned below respectively. The first two phases follow the same algorithm that SWOT analysis does.

Phase I. Analysis of internal and external factors

The analysis process performs in the internal factors evaluation (IFE) and external factors evaluation (EFE) matrices. The strengths and weaknesses of the organization are listed in the IFE matrix as internal factors. Generally, IF analysis is based on financial statements (sales, cost, revenue, productivity and etc). Also, the basis of EF analysis is GPESTEL (globalization, political, economic, social, technical, environmental and legal) indicators analysis. 
Phase II. Construction of SWOT matrix.

SWOT matrix is constructed on internal and external factors platform. Typically, organization strategies are assessed in the SWOT matrix. As mentioned, there are four strategic positions. Each position has its original nature and strategies. The derived strategies are the resultant of external and internal factors.

Phase II.I. Selection of the Strategies (All strategic positions)

In the SWO analysis original process, at first, the algorithm assesses the strategic position, then strategies are determined according to the strategic position. In this step, regardless of organization's strategic position all strategies (ST, SO, WT, WO) are determined.

Phase II.II. Determination of strategic position and selection of the strategies in accordance to the strategic position

Strategic position assessment is a formulated process. The intersection of IEEM and IFEM total scores expresses the organization strategic position.

Phase III. Computation of (VI)

The main core of the proposed framework is the computation of VI. VI is a value extracted from a mathematical algorithm based on entropy that describes the range of interaction of strategies on each other. VI model has been displayed in the following figure.

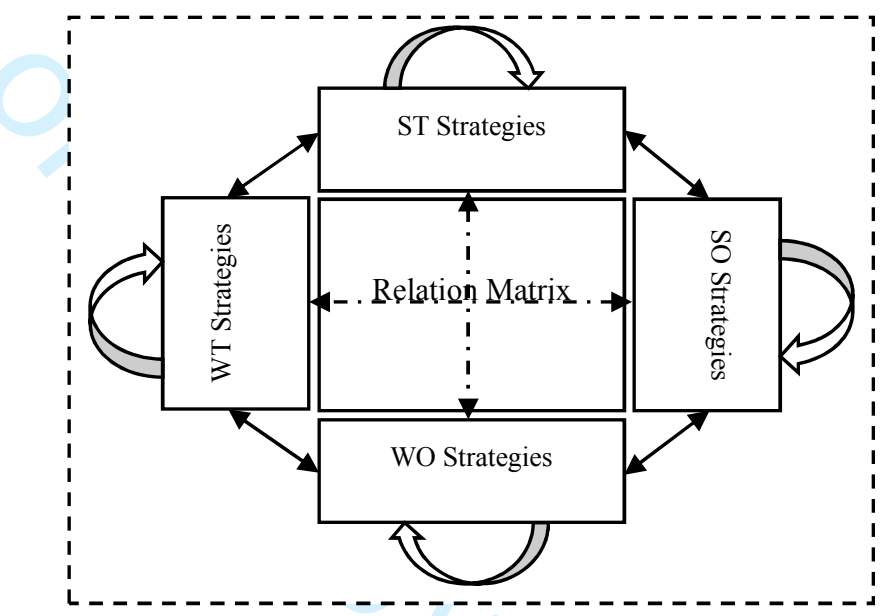

Fig 2. The Proposed Strategies Interaction Model (SIM)

Phase IV. Ranking of the selected Strategies

With the impact of VI as the coefficient of alternatives, the selected strategies will be prioritized.

Phase V. Evaluation and selection of the alternative strategies

\section{Real world application and results}

In this section, we discuss a real-world application of SIM' model to consider a project of strategic planning and SWOT analysis the case of a large-scale dairy enterprise, which has a turnover in excess of 100 million dollars. The employees are more than 1200 , and it is located in the north of Iran.

5.1. Case study: an overview

With an effective R\&D department and innovative approaches to production and processes, also with the supplying of high-quality raw material, this company produces various groups of products. The mentioned processes must be transferred into a fiscally disciplined platform. In this company, there is no standard software platform for the integration of business processes and resources (ERP). The company lacks the businesslike marketing research, branding, and the developed distribution planning that is required for the domestic and export markets penetration. For the $\mathrm{DSR}^{1}$ (where demand exceeds supply) and attractive dairy markets for exporting of products such as Iraq, Russia, and Afghanistan, the dairy industry is an attractive opportunity for investment. In recent years, the economic issues, sanctions, and fluctuations in international political relations have affected domestic legislation, domestic political context, cash flows, and finally on the purchasing power of the public.

5.2. Data Collection

With a short introduction about the company and its industrial environment, the strengths and weaknesses are provided in (Table 3 ). The goals of applying SIM are to select the best strategies and determine the best alternative strategies. The proposed model has been already implemented in the company as its one of the strategic planning parts (FY² 2017).

Table 3

Synthesis of SWOT analysis

\begin{tabular}{|c|c|c|c|c|c|c|c|}
\hline \multicolumn{2}{|c|}{ Strengths } & \multicolumn{2}{|c|}{ Weaknesses } & \multicolumn{2}{|c|}{ Opportunities } & \multicolumn{2}{|c|}{ Threats } \\
\hline $\mathrm{S}_{1}$ & High quality products & $\mathrm{W}_{1}$ & Market research & $\mathrm{O}_{1}$ & Untapped domestic markets & $\mathrm{T}_{1}$ & $\begin{array}{l}\text { Fluctuations in the economic and } \\
\text { governmental laws }\end{array}$ \\
\hline $\mathrm{S}_{2}$ & $\begin{array}{l}\text { Usage of high quality raw } \\
\text { materials }\end{array}$ & $\mathrm{W}_{2}$ & Branding & $\mathrm{O}_{2}$ & $\begin{array}{l}\text { Untapped markets for } \\
\text { exportation }\end{array}$ & $\mathrm{T}_{2}$ & Strong competitors (newcomers) \\
\hline $\mathrm{S}_{3}$ & Innovation and variety & $\mathrm{W}_{3}$ & ERP Software & $\mathrm{O}_{3}$ & $\begin{array}{l}\text { orientation of society healthy } \\
\text { products }\end{array}$ & $\mathrm{T}_{3}$ & $\begin{array}{l}\text { Fluctuations in international political } \\
\text { relations }\end{array}$ \\
\hline
\end{tabular}

${ }^{1}$ Demand to Supply Ratio

${ }^{2}$ Fiscal Year 
Fluctuations in the purchasing power of the people

$\mathrm{T}_{5} \quad$ SUBSTITUTE GOODS

5.3. SIM application and results

5.3.1. Analysis of internal and external factors

To evaluate internal and external factors and also for calculating the score (weighted rank), there is a typical formula which is based on the multiplication of importance with the weight and rank. In this paper, a developed form of Delphi panel has been utilized for evaluation of internal and external factors.

\subsubsection{Delphi panel and analysis}

The objective of the Delphi group in this study is the achievement of a consensus based on the discussion among experts (Párraga, et al. 2014). According to the selection process, the expert panel has been composed into the theoretical and practical experts, where the theoretical experts are the company consultants (consultants of economic and finance, strategic and systems, and marketing and sales) and executive vice presidents of (strategy and HR); Experts on practical matters are executive vice presidents (production and QC), (sales and operations), (production groups and marketing) and (finance, IT and investment). The numerical scale of the questionnaire is portrayed in Fig. 3.

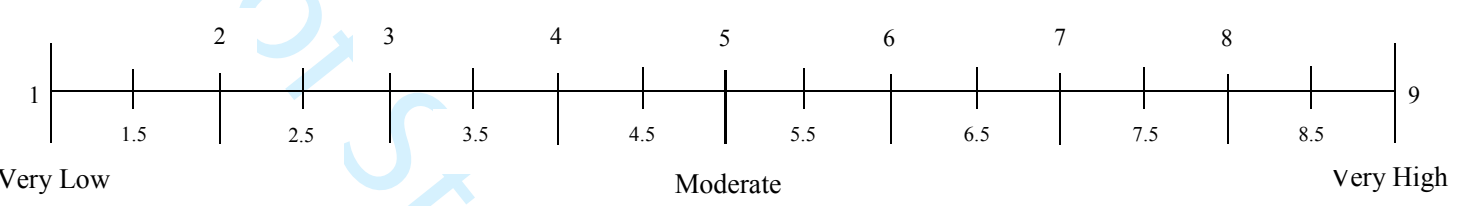

Fig 3. Numerical scale of weighting and rating; the scale includes three ranges of very low, moderate high and very high. Other groups of linguistic variables such as low, moderate low, high and moderate high have not been specified and DM chooses the numbers between very low, moderate and very high as his/her option.

To analyze the obtained data from the questionnaire, this paper proposed a developed Delphi analysis. The proposed method foundation is the weight of decision makers (WDMs). According to the WDMs, with respect to each group members' decisions, a special importance weight is tagged on the groups of theoretical and practical experts. The weights of expert groups are in accordance with the entropy of their decisionmaking. In a numerical space, the proposed algorithm of Delphi computes WDMs using the entropy (Eq.17-19) of decisions. The final results of the panel have been demonstrated in (Table 4).

Table 4

Integration of $\left(W D M s_{j}\right)$ and $(W D M s)$ of importance weight. "WDMs" has been calculated by sum of simple averages (SA) of each expert group's decisions.

\begin{tabular}{|c|c|c|c|c|c|c|c|c|}
\hline & \multicolumn{4}{|c|}{ Theoretical Experts } & \multicolumn{4}{|c|}{ Practical Experts } \\
\hline & $C_{1}$ & $C_{2}$ & $C_{3}$ & $V P_{1}$ & $V P_{2}$ & $V P_{3}$ & $V P_{4}$ & $V P_{5}$ \\
\hline$W D M s_{1} j$ & 0.1839 & 0.0847 & 0.1826 & 0.1860 & 0.0577 & 0.1294 & 0.0901 & 0.0856 \\
\hline$W D M s_{1} j$ & 0.1133 & 0.1497 & 0.1025 & 0.1133 & 0.1663 & 0.1025 & 0.1497 & 0.1025 \\
\hline$W D M s_{2} j$ & 0.0056 & 0.9649 & 0.0018 & 0.0083 & 0.0069 & 0.0052 & 0.0051 & 0.0022 \\
\hline$W D M s_{2} j$ & 0.1353 & 0.1562 & 0.1562 & 0.1353 & 0.1219 & 0.0881 & 0.1036 & 0.1036 \\
\hline$S A_{W D M s_{j}}$ & 0.110 & 0.339 & 0.111 & 0.111 & 0.088 & 0.081 & 0.087 & 0.073 \\
\hline WDMs & \multicolumn{4}{|c|}{0.670} & \multicolumn{4}{|c|}{0.330} \\
\hline
\end{tabular}

\subsubsection{Construction of the SWOT matrix}

This section includes two parts as 1.selection of the strategies through resulatant of the internal and external factors; and 2. Determination of strategic position and selection of the strategies in accordance to the strategic position.

5.3.2.1. Selection of the Strategies

As mentioned, the derived four strategies groups from SWOT are the resultants of the strengths and opportunities, strengths and threats, weaknesses and opportunities, and the weaknesses and threats. Thus, regardless of the strategic positions, they have been determined as: 1 . The aggressive strategies (SO group), which are the resultant of strengths and opportunities include the domestic market development $\left(S_{1} S_{3} O_{1}\right)$, export market development $\left(S_{1} S_{3} O_{2}\right)$, and the development of healthy and probiotic products $\left(S_{3} S_{5} O_{3}\right)$ abbreviated to $\left(S_{1}, S_{2}, S O_{3}\right)$ respectively; 2. in regard to the company's strengths and environmental threats, as competitive strategies, the competitive price by reducing product costs $\left(S_{5} T_{2} T_{4}\right)$, and the diversification $\left(S_{5} T_{2} T_{5}\right)$ abbreviated to the $\left(S T_{1}\right.$ and $\left.S T_{2}\right)$ have been determined as the (ST) group of strategies; 3. To cover the weaknesses with environmental opportunities, the marketing mix development $\left(W_{1} W_{2} W_{4} O_{1} O_{2} O_{3}\right)$, and the increasing number of the DCs $\left(W_{4} O_{1}\right)$ which are assigned to the $\left(W O_{1}, W O_{2}\right)$. These strategies are selected as the conservative strategies, abbreviated as (WO) group of strategies.; and finally The increasing brand equity $\left(W_{2} T_{2} T_{5}\right)$, and the product development by investment on R\&D $\left(W_{1} T_{2} T_{4} T_{5}\right)$ abbreviated as $\left(W T_{1}, W T_{2}\right)$ have been specified as the defensive strategies in the group of (WT) strategies, where marketing mix is the single statement of combination of marketing four "P(s)" including product, place, promotion, and price. Moreover, DC denotes a distribution center and R\&D mentions research and development processes.

5.3.2.2. Determination of strategic position and selection of the strategies in accordance to the strategic position

To find what strategy plays the pathfinder role to lead the company policies and resources for the current and future situations, the strategic position of the company must be determined. There is a classic methodology for calculation of the company strategic position. In the classic version, the weights of importance multiply in rank and the score specifics the strategic position. While in this paper we introduced (WDMs), which multiplies in the weights of importance and the results will be multiplied in the rank. The following equations show the mentioned procedure, where $(W)$ is the weight of importance and $\left(N_{(W D M S \times W)}\right)$ is the normalized number of $\left(W D M s_{j} . W\right)$ with respect to the Eq.(19), $W D M s_{1}$ is for theoretical and $W D M s_{2}$ is for practical experts and $\left(W_{1}\right),\left(W_{2}\right)$ mentioned to the theoretical experts decisions and practical experts respectively. 
Calculation process of scores is shown in (Table 5,6).

Table 5

Scores of internal factors where the weights of importance and rankings are the SA of DMs in each experts group.

\begin{tabular}{|c|c|c|c|c|c|c|c|c|c|c|}
\hline & & \multicolumn{3}{|c|}{ Theoretical experts } & \multicolumn{5}{|c|}{ Practical experts } & \multirow[b]{2}{*}{ score } \\
\hline & & $W D M s_{1}$ & $W_{1}$ & $N$ & Rank & $W D M s_{2}$ & $W_{2}$ & $N$ & rank & \\
\hline \multirow{5}{*}{ 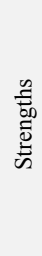 } & High quality products & 0.670 & 8.50 & 0.116 & 3.75 & 0.330 & 8.88 & 0.118 & 4.00 & 0.45 \\
\hline & Usage of high quality raw materials & 0.670 & 7.50 & 0.103 & 3.00 & 0.330 & 8.00 & 0.107 & 3.25 & 0.33 \\
\hline & Innovation and variety & 0.670 & 8.25 & 0.113 & 4.00 & 0.330 & 8.38 & 0.112 & 3.75 & 0.43 \\
\hline & $\begin{array}{l}\text { Fiscal discipline ((revenues, } \\
\text { expenses and obligations)) }\end{array}$ & 0.670 & 8.63 & 0.118 & 3.75 & 0.330 & 8.50 & 0.113 & 3.25 & 0.40 \\
\hline & Flexible production & 0.670 & 7.25 & 0.099 & 3.00 & 0.330 & 7.88 & 0.105 & 3.25 & 0.32 \\
\hline \multirow{4}{*}{  } & Market research & 0.670 & 8.50 & 0.116 & 2.00 & 0.330 & 8.25 & 0.110 & 2.00 & 0.23 \\
\hline & Branding & 0.670 & 8.38 & 0.115 & 1.75 & 0.330 & 8.50 & 0.113 & 1.50 & 0.19 \\
\hline & ERP Software & 0.670 & 7.50 & 0.103 & 1.00 & 0.330 & 7.88 & 0.105 & 1.25 & 0.12 \\
\hline & Distribution & 0.670 & 8.63 & 0.118 & 2.00 & 0.330 & 8.75 & 0.117 & 1.75 & 0.22 \\
\hline
\end{tabular}

Table 6

Scores of external factors where the weights of importance and rankings are the SA of DMs in each experts group.

\begin{tabular}{|c|c|c|c|c|c|c|c|c|c|c|}
\hline & & \multicolumn{3}{|c|}{ Theoretical experts } & \multicolumn{5}{|c|}{ Practical experts } & \multirow[b]{2}{*}{ scor } \\
\hline & & $W D M s_{1}$ & $\overline{W_{1}}$ & $N$ & rank & $W D M s_{2}$ & $W_{2}$ & $N$ & rank & \\
\hline \multirow{3}{*}{ 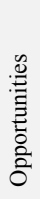 } & Untapped domestic markets & 0.670 & 8.5 & 0.141 & 4 & 0.330 & 8.625 & 0.143 & 4 & 0.57 \\
\hline & Untapped markets for exportation & 0.670 & 8.125 & 0.135 & 3.5 & 0.330 & 8.25 & 0.137 & 3.25 & 0.46 \\
\hline & $\begin{array}{l}\text { orientation of society to healthy } \\
\text { products }\end{array}$ & 0.670 & 6.75 & 0.112 & 3 & 0.330 & 7.125 & 0.118 & 3.25 & 0.35 \\
\hline \multirow{6}{*}{ 苞 } & $\begin{array}{l}\text { Fluctuations in the economic and } \\
\text { governmental laws }\end{array}$ & 0.670 & 7.625 & 0.127 & 1.75 & 0.330 & 7.375 & 0.122 & 2 & 0.24 \\
\hline & Strong competitors (newcomers) & 0.670 & 7.75 & 0.129 & 1.25 & 0.330 & 7.875 & 0.130 & 1.75 & 0.19 \\
\hline & $\begin{array}{l}\text { Fluctuations in international } \\
\text { political relations }\end{array}$ & 0.670 & 8.25 & 0.137 & 1 & 0.330 & 7.625 & 0.126 & 1.5 & 0.17 \\
\hline & $\begin{array}{l}\text { Fluctuations in the purchasing } \\
\text { power of the people }\end{array}$ & 0.670 & 8.625 & 0.143 & 2 & 0.330 & 8.875 & 0.147 & 2 & 0.29 \\
\hline & SUBSTITUTE GOODS & 0.670 & 4.5 & 0.075 & 1 & 0.330 & 4.625 & 0.077 & 1 & 0.07 \\
\hline & & & & & & & & \multicolumn{2}{|c|}{ Total Score } & 2.34 \\
\hline
\end{tabular}

According to Fig.4, the resultant of two total scores of internal and external factors specify the company's strategic positions.

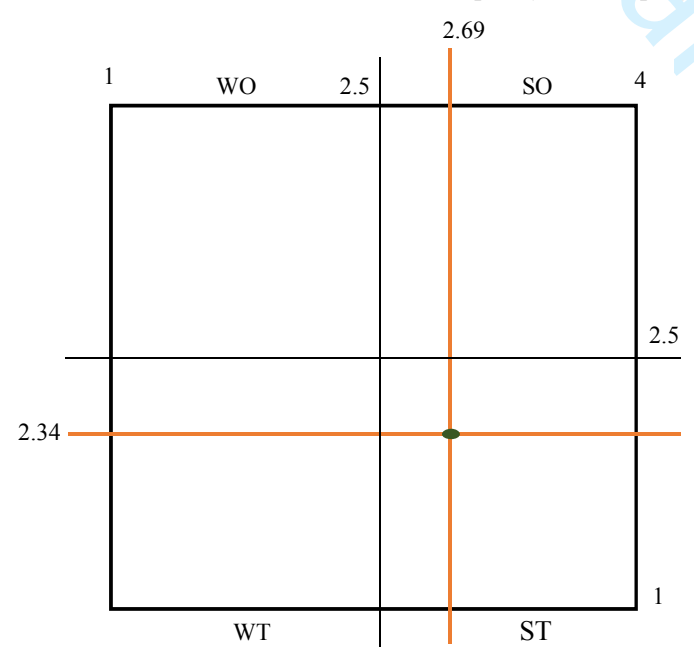

Fig 4. Graphical structure: determination of strategic position. 
As portrayed in Fig.4, strategic position of the company is the (ST). Thus, competitive strategic position must be selected as the result of this phase. Consequently, two strategies of "competitive price by reducing product costs, and diversification" are the selected strategies.

\subsubsection{Computation of $V I$}

As shown in Fig.2, $V I$ is the value of interaction between two groups of strategies. ( $V I)$ structure is built on the entropy concept which describes how much strategies affect each other. In $(V I)$ mathematical framework, the impact of all groups of strategies on the selected strategies are investigated due to the strategic position determination. As mentioned earlier, the grey functions are employed to avoid imprecision and uncertainty of DMs decisions. In this paper, all computations are performed in the grey environment. Following phases show the (VI) calculation algorithm.

Phase I. Construction of a decision matrix.

First, all groups of strategies are considered as alternatives, and the selected strategies are assumed as criteria. Then, in the next constructed decision matrix, selected strategies are considered as alternatives and other groups of strategies which includes selected groups of strategies are considered as criteria. In the decision matrix, decisions are based on DMs assessment about the relation between members of two groups of the strategies; In fact, the decision matrix is a relation matrix. In this paper, the relation matrices are not the same as the pairwise comparison matrices and they follow the classical MCDM algorithm. DMs decisions are the linguistic variables which they have been discussed earlier. The transformation illustration of linguistic variables to grey numerical variables in a relation matrix is as follows in Fig.5.

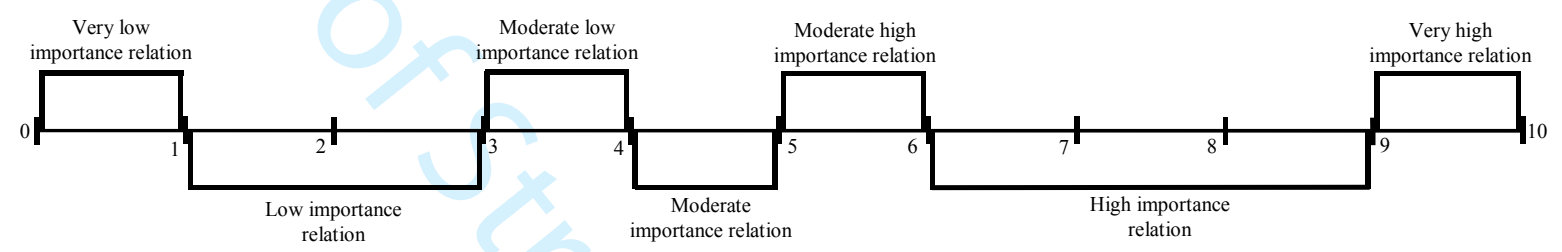

Fig 5. Numerical scale for relation matrix: linguistic variables and their corresponding numerical variables

Phase II. Normalization of decision matrix with respect to the Eq. $(15,16)$.

Phase III. Computation of Entropy according to the Eq.(11-14).

Phase IV. Computation of weight of each criterion: The weights denote range of interaction of criteria on alternatives.

5.3.3.1. Interaction between strategies

Calculation process of interactions is in the grey environment. As mentioned, a grey number is a numerical interval that includes lower and upper bounds. In decision-making processes, In other words, DM's decision is located somewhere between these two bounds. In this paper, there are eight DMs who provided their decisions as the organizational experts. We proposed a simple approach to select the interval, which supports the most likely existence probability of the right number that all DMs mention. In the proposed approach, the smallest lower bound and the highest upper bound of DM's decisions have been selected. The constructed interval by those two bounds is the basis of the computing process. The concept of the mentioned interval computation has been portrayed in Fig.6:

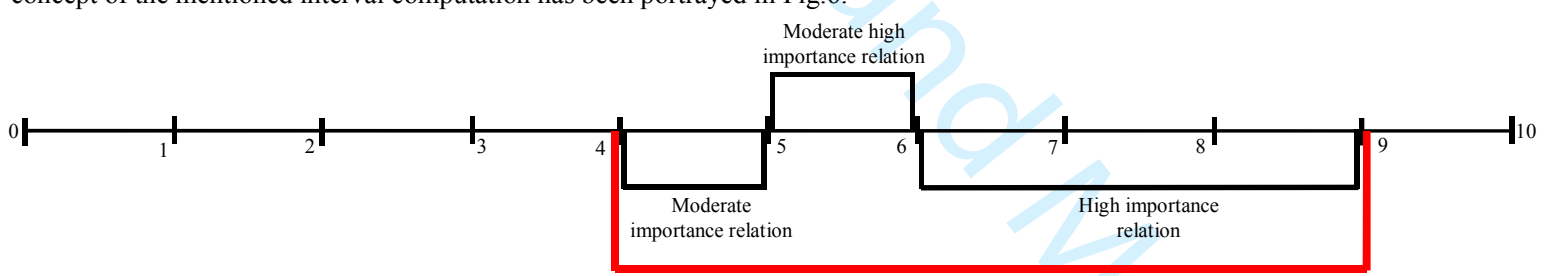

Fig 6. Graphical concept of the mentioned interval computation: for instance, let suppose DMs decisions are the intervals of [4,5], [5,6] and $[6,9]$, the right interval for computation of interaction is $[4,9]$ where the DMs decisions are between the lowest and the highes intervals (red line).

Moreover, the interval can be computed as following equations.

$\underline{G_{i j}^{\prime}}=\sum_{i=1}^{n} K \underline{G_{i j}} \cdot\left(\sum_{i=1}^{n} K\right)^{-1}$

$\overline{G_{i j}^{\prime}}=\sum_{i=1}^{n} K \overline{G_{i j}^{\prime}} \cdot\left(\sum_{i=1}^{n} K\right)^{-1}$

where $\otimes G_{i j}^{\prime}=\left[G_{i j}^{\prime}, \overline{G_{i j}^{\prime}}\right], \otimes G_{i j}=\left[G_{i j}, \overline{G_{i j}}\right]$ and $(K)$ is the number of each upper and lower bound of $\otimes G_{i j}$ in the experts decision matrix. In this paper, the first approach has been utilized to compute the intervals.

The final step is the calculation of VI. This procedure subtends following phases:

Phase I. Computation of each strategies score

As discussed earlier, each strategy is a resultant of the internal and external factors. According to the (Table 5,6), the scores are the result of the sum of the strengths, threats, opportunities, and threats in each strategy. Hence, the derived scores are $\left(S_{1}: S_{1} S_{3} O_{1}: 1.45 ; S_{2}: S_{1} S_{3} O_{2}: 1.34\right.$; $\left.S O_{3}: S_{3} S_{5} O_{3}: 1.21\right)$ as the scores of the (SO) group strategies, $\left(S T_{1}: S_{5} T_{2} T_{4}: 0.71 ; S T_{1}: S_{5} T_{2} T_{5}: 0.58\right)$ as the scores of the (ST) group strategies, $\left(W O_{1}: W_{1} W_{2} W_{4}\right.$ $\left.O_{1} O_{2} O_{3}: 2.02 ; W O_{2}: W_{4} O_{1}: 0.79\right)$ as the scores of the (WO) group strategies, and $\left(W T_{1}: W_{2} T_{2} T_{5}: 0.62 ; W T_{2}: W_{1} T_{2} T_{4} T_{5}: 0.78\right)$ as the scores of the (WT) group strategies.

Phase II. Computation of VI

As desplayed in (Table 7), for compution of (VI), decision matrix needs to be constructed which the derived normalized scores from (phase 1) are the $\left(\lambda_{j}\right)$ and the numbers in the decision matrix are the set of $\left(W_{j}\right)$. Following Eq.(19,20), $V I$ is the weight of each strategy as the criteria. 
Table 7

Computation of $V I$

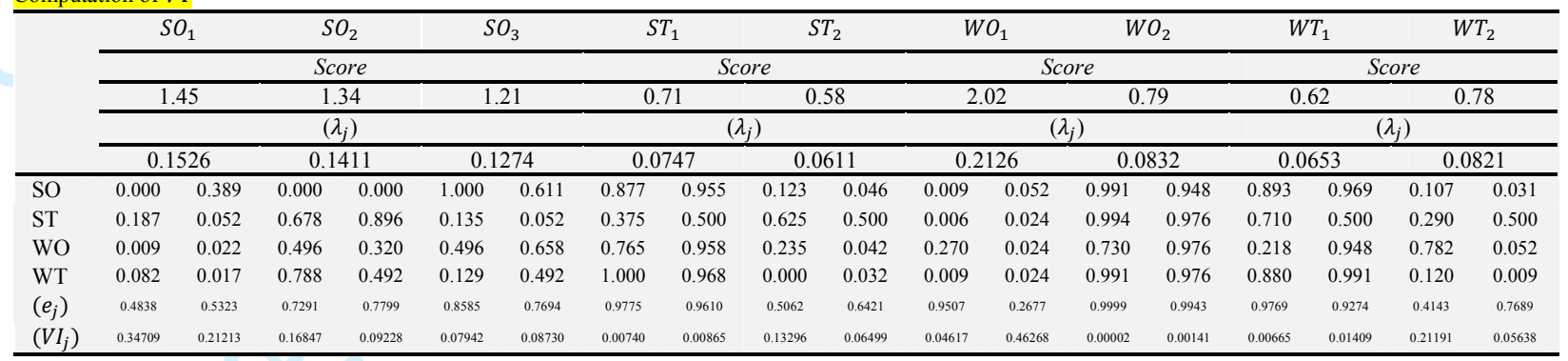

5.3.4. Ranking of the selected Strategies

According to (Table 15), with the construction of the decision matrix, $(S T)$ is ranked. In the decision matrix, $(V I)$ of $(S O, W O, W T)$ strategies are the weight of criteria as $\left(V I_{j}\right)$ and $\left(V I_{i}\right)$ is the weight of alternatives which affects on ranking. In regard to to (Table 15$)$, $\left(S O_{1}, S O_{2}\right.$, $\left.S O_{3}, W O_{1}, W O_{2}, W T_{1}, W T_{2}\right)$ are the criteria and $\left(S T_{1}, S T_{2}\right)$ are as the alternatives. In Accordance with Eq.(25), for the ranking of strategies, grey WPM has been employed. For an instance, following tables (Table 8,9) show the ranking procedure of ST group strategies. The numbers of decision matrix are based on experts decisions which are extracted from tables of interactions computation. The weights of (ST) strategies are not normalized.

Table 8

Ranking of $S T$ strategies with application of $\left(V I_{i}\right)$ on the normalized decision matrix (where $\left(V I_{j}\right)$ have been normalized as the weights of criteria) as the weight of criteria, regarding to the proposed grey WPM formula.

\begin{tabular}{|c|c|c|c|c|c|c|c|c|c|c|c|c|c|c|c|c|}
\hline \multirow[t]{3}{*}{$W_{j}$} & 0.19434 & 0.11877 & 0.09433 & 0.05167 & 0.04447 & 0.04888 & 0.02585 & 0.25906 & 0.00001 & 0.00079 & 0.00372 & 0.00789 & 0.11865 & 0.03157 & & \\
\hline & \multicolumn{2}{|c|}{$\mathrm{SO}_{1}$} & \multicolumn{2}{|c|}{$\mathrm{SO}_{2}$} & \multicolumn{2}{|c|}{$\mathrm{SO}_{3}$} & \multicolumn{2}{|c|}{$W O_{1}$} & \multicolumn{2}{|c|}{$W O_{2}$} & \multicolumn{2}{|c|}{$W T_{1}$} & \multicolumn{2}{|c|}{$W T_{2}$} & \multirow{2}{*}{$\left(P_{i}\right)$} & \multirow{2}{*}{ Rank } \\
\hline & $\underline{G_{i j}}$ & $\overline{G_{i j}}$ & $\underline{G_{i j}}$ & $\overline{G_{i j}}$ & $\underline{G_{i j}}$ & $\overline{G_{i j}}$ & $\underline{G_{i j}}$ & $\overline{G_{i j}}$ & $\underline{G_{i j}}$ & $\overline{G_{i j}}$ & $\underline{G_{i j}}$ & $\overline{G_{i j}}$ & $\underline{G_{i j}}$ & $\overline{G_{i j}}$ & & \\
\hline$S T_{1}$ & 0.500 & 0.600 & 0.500 & 0.500 & 0.333 & 0.375 & 0.546 & 0.526 & 1.000 & 0.667 & 0.000 & 0.375 & 0.143 & 0.375 & 6.9963 & 1 \\
\hline$S T_{2}$ & 0.500 & 0.400 & 0.500 & 0.500 & 0.667 & 0.625 & 0.455 & 0.474 & 0.000 & 0.333 & 1.000 & 0.625 & 0.857 & 0.625 & 6.9814 & 2 \\
\hline
\end{tabular}

Table 9

Ranking of $S T$ strategies with application of $\left(V I_{j}\right)$ as the weight of alternatives.

\begin{tabular}{ccccc}
\hline \multirow{2}{*}{ Strategies } & \multicolumn{2}{c}{$\left(V I_{i}\right)$} & $\left(P_{i}\right)$ & Score \\
\cline { 2 - 3 } & $G_{i j}$ & $\overline{G_{i j}}$ & 6.9963 & 0.112291 \\
$S T_{1}$ & 0.00740 & 0.00865 & 6.9814 & 1.381968 \\
\hline$T_{2}$ & 0.13296 & 0.06499 & Rank & 1 \\
\hline
\end{tabular}

As exhibited in (Table 9), the larger value of $\left(P_{i}\right)$ is expected. In the process, score has been calculated as following equation:

Score $_{j}=\sum_{j=1}^{n}\left(\underline{G_{i j}}+\overline{G_{i j}}\right)\left(V I_{i}\right) \quad i=1,2, j=1,2$;

5.3.5. Evaluation and selection of the alternative strategies

The basis of alternative strategies selection is the larger value of $\left(V I_{j}\right)$ in each strategies group. As it is noted before, $\left(V I_{j}\right)$ is a grey number and for computation of $\left(V I_{j}\right)$, this paper proposed a transferring equation (Eq.27), called the grey importance value $(G I V)$. Let us consider $\otimes G_{i}=$ $\left[\underline{G_{i}}, \overline{G_{i}}\right]$ and $(\xi)$ is a random variable where $\left(\xi<\underline{G_{1}}\right)$ and $\left(\xi<\overline{G_{1}}\right)$;

Then,

The neighbor numbers of $\otimes G_{i}$ are

$\otimes G_{i+\xi}=\left[\left(\underline{G_{i}}+\xi\right),\left(\overline{G_{i}}+\xi\right)\right]$

$\otimes G_{i-\xi}=\left[\left(\underline{G_{i}}-\xi\right),\left(\overline{G_{i}}-\xi\right)\right]$

Where $\left(\otimes G_{i+\xi} \geq \otimes G_{i}\right)$ and $\left(\otimes G_{i-\xi} \leq \otimes G_{i}\right)$

Therefore (GIV) is as Eq.(27):

$G I V=\left(\sqrt{\left(\left(\frac{\left(\left(\overline{G_{i}}-\xi\right)+\overline{G_{i}}+\left(\overline{G_{i}}+\xi\right)\right)^{2}}{\left(\overline{G_{i}}-\xi\right)^{2}+\bar{G}_{i}^{2}+\left(\overline{G_{i}}+\xi\right)^{2}}\right)-\left(\frac{\left(\left(\underline{G_{i}}-\xi\right)+\underline{G_{i}}+\left(\underline{G_{i}}+\xi\right)\right)^{2}}{\left(\underline{G_{i}}-\xi\right)^{2}+\underline{G}_{i}^{2}+\left(\overline{G_{i}}-\xi\right)^{2}}\right)^{2}\right.}\right)^{-1}$

$(G I V)$ s of each strategies in strategies groups of $(S O, W O, W T)$ are shown in (Table 10) where $\left(\xi_{S O}=0.01, \xi_{W T}=0.001\right.$ and $\left.\xi_{W O}=0.00001\right)$.

Selection of $(\xi)$ follows a simple order. In the proposed process, the smallest number needs to be chosen between the bounds of each grey number in groups. Then it needs to the number of (1) must be left instead of the last number of the bounds. For instance, following equations ilustrate the selection of $(\xi)$ for strategy group of (WO). 
And

$W O_{2}=[0.00002,0.00141]$

The smallest number between four bounds (two lower, and two upper bounds) of the grey numbers is $(0.00002)$ thus according to the selection of $(\xi)$ instruction it just need to leave number of (1) instead of the last number of the (0.00002). Therefore the $(\xi=0.00001)$.

Table 10

Grey value importance for each strategy

\begin{tabular}{|c|c|c|c|c|c|c|c|c|}
\hline \multicolumn{3}{|c|}{ SO } & \multicolumn{3}{|c|}{$W T$} & \multicolumn{3}{|c|}{ WO } \\
\hline Strategies & $V I_{j}$ & GIV & Strategies & $V I_{j}$ & GIV & Strategies & $V I_{j}$ & GIV \\
\hline $\mathrm{SO}_{1}$ & {$[0.34709,0.21213]$} & 359.877 & $W T_{1}$ & {$[0.00665,0.01409]$} & 28.974 & $W O_{1}$ & {$[0.04617,0.46268]$} & 10765544 \\
\hline $\mathrm{SO}_{2}$ & {$[0.16847,0.09228]$} & 61.449 & $W T_{2}$ & {$[0.21191,0.05638]$} & 1710.811 & $W_{2}$ & {$[0.00002,0.00141]$} & 2.334 \\
\hline $\mathrm{SO}_{3}$ & {$[0.07942,0.08730]$} & 186.506 & & & & & & \\
\hline
\end{tabular}

Therefore, in respect of (Table 10), alternative strategies are $\left(W O_{1}, W T_{2}, S O_{1}\right)$, where $\left(W O_{1}=10765544>W O_{2}=2.334\right)$, $\left(W T_{2}=\right.$ $\left.1710.811>W T_{1}=28.974\right)$ and $\left(S O_{1}=359.877>S O_{3}=186.506, S O_{2}=61.449\right)$. In addition to (ST) strategies, the company can implement them as well. The Selection of alternative strategies is in accordance with the larger value of (GIV)

\section{Discussion and conclusions}

A strategy is a concept that shows how an organization must move from the current position to the next planned position. It is like a canvas, which organization major goals, policies, and action plans are portrayed on. Strategic planning is a part and parcel of strategy. It is a statistical conformation a decision-making based tool to define the organization's mission, goals, strategy, direction, and audience to allocate the resources due to the strategy (mission and goals). Moreover, strategic planning has been described as a process of strategies selection and definition, an alignment of strategies and decision making for the resource allocation. For planning of the goals and allocating the resources, typically strategic planning deals with the STEER analysis (Socio-cultural, Technological, Economic, Ecological, and Regulatory factors), PEST analysis (Political, Economic, Social, and Technological analysis), PESTEL analysis (Political, Economic, Social, Technological, Environmental and Legal), EPISTEL analysis (Environment, Political, Informatics, Social, Technological, Economic, and Legal), and the SWOT analysis (Strengths, Weaknesses, Opportunities, and Threats).

SWOT is one of the most popular business and strategic analysis tools, which widely used to identify the strengths and weaknesses of the organization as internal factors, and determination of the opportunities and threats of the organization environment as the external factors. Internal factors indicate strengths and weaknesses of the organization and external factors explain opportunities and threats, which impact the organization behavior frequently. The strategies are the result of internal and external factors. The derived strategies from the SWOT analysis process play the role of minimizing threats by focusing on strengths and maximizing possible available advantages via opportunities.

As denoted heretofore, the traditional SWOT process identifies internal and external factors and integrates them into a matrix, then offers four strategies groups of SO, ST, WO, and WT strategies. however, it is not effective for strategy formulation and planning. In the strategic planning process, the classic SWOT analysis procedure combines five phases including 1. Identification of internal and external factors, then construction of IFE and EFE matrices; 2. Making SWOT matrix; 3. SWOT matrix analysis; 4. Construction of quantitative strategic programming matrix (QSPM matrix); 5. Ranking the identified strategies to propose organization operational strategies. The QSPM matrix evaluates selected strategies groups (ST, SO, WT or WO) against internal and external factors, while it ignores other groups of possible strategies and does not offer a framework to choose alternative strategies. Furthermore, it ignores the impact of strategies on each other. In this paper, we aimed to cover the gap of classic SWOT analysis, and also the ignorance of the organization strategic position in the hybrid MCDM-SWOT methodologies. The decision-making stage of SWOT analysis is the area where the authors proposed MCDM-based methodologies to select organization strategies. For the selection of the strategies in the SWOT analysis procedure, this paper presented a proposed model calls strategies interaction model (SIM). This paper comprehends eight sections including Literature review, method and tools, proposed methodology, data collection, application and result, discussion and conclusion, and future works. In the paper, we described the SWOT analysis procedure and reviewed the literature on hybrid model of MCDM-SWOT analysis. Application of TOPSIS, AHP, ANP, Entropy, DEMATEL, DEA and linear programming are investigated in the literature review section. As discussed in the literature section, there is no paradigm to designate the organization strategic position in the MCDM-SWOT hybrid frameworks. Moreover, they ignore organization strategic position in the process of the strategiies selection. To solve the aforementioned gaps, we proposed an interaction model, which is described in the proposed methodology section. The output of SIM offers alternative strategies for each strategic positions. The ranking procedure is in accordance with the strategies interactions. For the comparison, the following figures show the strategies selection process of the studied company in AHP method and SIM model.

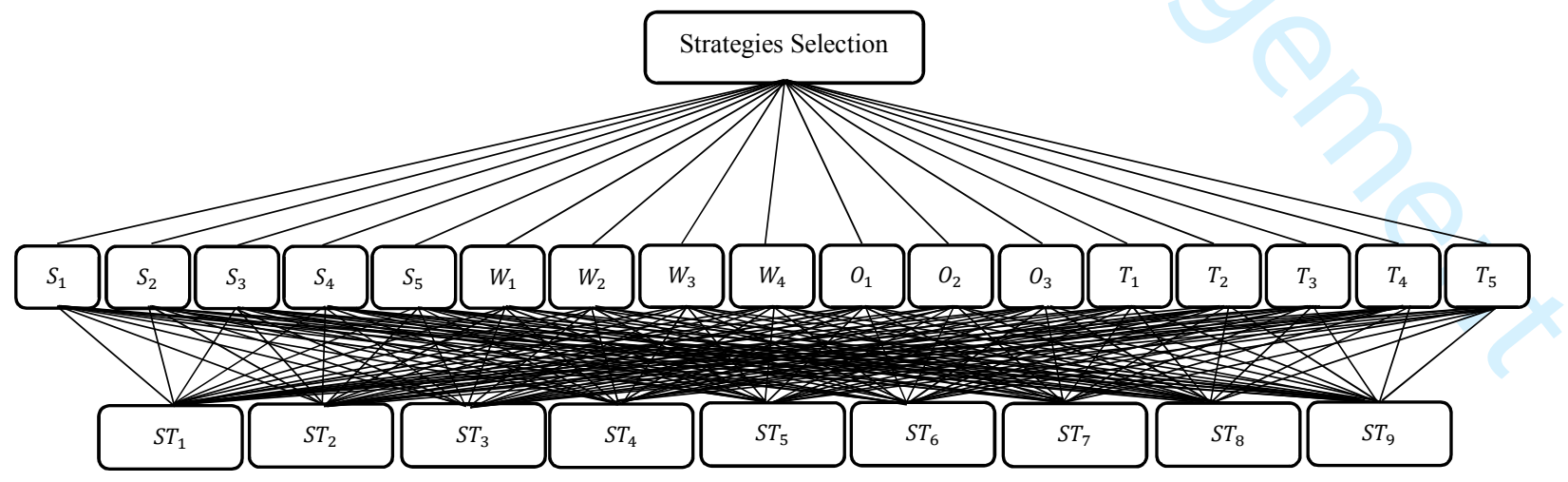


Fig 7. AHP structure: the case study strategies selection procedure

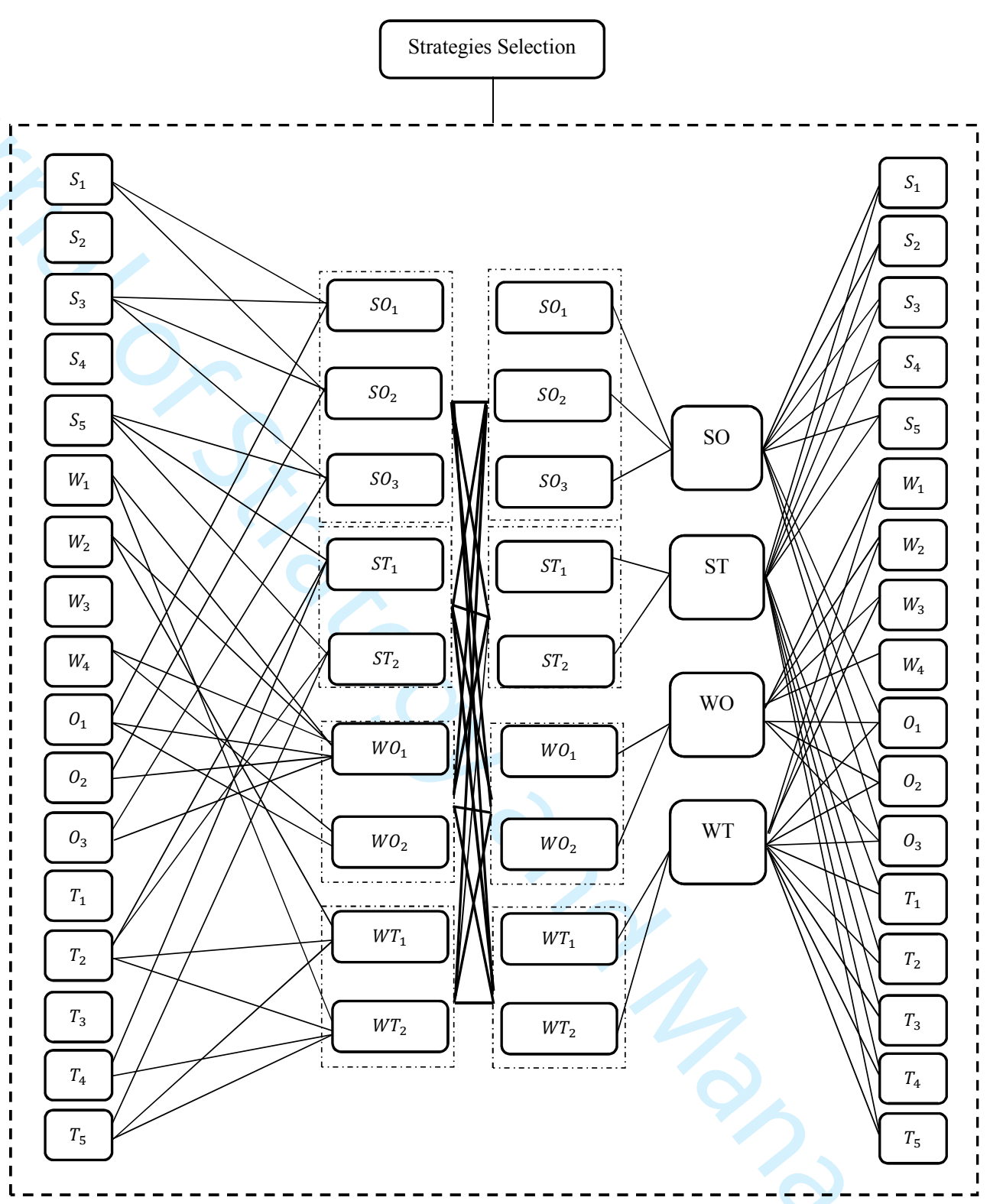

Fig 8. SIM structure: the case study strategies selection procedure

As exposed in (Fig 7), with only proposition of the strategies ranking process and without consideration of the strategic positions, AHP selects strategies in accordance to the internal and external factors, while after determination of strategic positions, SIM procedure selects strategies based on the interaction of strategies (see Fig 8).

Strategic planning starts with the determination of the strategic positions and SIM is a useful tool for the strategic planning projects. SIM is proposed in two areas of evaluation and selection (see Fig 1). The section of evaluation contains following steps: analysis of internal factors and analysis of external factors (simultaneously), construction of SWOT matrix, determination of strategic position, computation of VI, ranking the selected strategies and evaluation of the alternative strategies respectively. The selection area includes the selection of the strategies (all strategic positions), selection of the strategies, and selection of the alternative strategies. SIM is implemented in the grey environment to harness realworld uncertainty. The key tool of the proposed methodology is Shannon's Entropy that is stated in the method and tools section. In addition, we proposed a grey form of the weighted product model, which is called GWPM (see Eq. 24,25).

In this paper, SIM has been applied in a case of dairy company. The company is a large-scale enterprise, which has a turnover in excess of 100 million dollars. The employees are more than 1200 , and it is located in the north of Iran. Internal and external factors of the company provided in (Table 3). With respect to the company's SWOT, "domestic market development, export market development, development of healthy and probiotic products" are selected as SO strategies, "competitive price by reducing product costs, diversification", "marketing mix development, increasing number of DCs", and "increasing brand equity, product development by investment on R\&D" have been extracted as ST, WO, and 
WT strategies respectively. As illustrated in (Fig 4), the competitive strategic position with ST strategies has been selected as the result of strategic position determination. The main core of the SIM is the value of interaction (VI). VI is a mathematical Entropy-based approach that describes the interaction range of strategies on each other (See Fig 2).

This paper proposed a developed form of Delphi panel as the base of group decision-making process for analysis of the obtained data from the questionnaire of the SIM. The panel includes the theoretical expert's category containing consultants (consultants of economic \& finance, strategic \& systems, and marketing \& sales) and executive vice presidents of (strategy and HR). Moreover, the executive vice presidents (production and QC), (sales and operations), (production groups and marketing) and (finance, IT and investment) have been hired as the expert of the practical matters. Also, the proposed math-based process uses a numerical scales of the questionnaires (see Fig 3). As shown in (Table 4), The procedure of the developed expert panel is in accordance with the weight of each DM. The proposed method deals with VI. It expresses how much strategies affect each other. In pursuant to the ranking of the selected strategies, increasing "brand equity" stands up the first place and "the product development by investment in R\&D" is in the second priority. Furthermore, marketing mix development and domestic market development are selected as the alternative strategies.

This paper attempts to solve the following problems: 1. Strategic position ignorance in combined methodologies of MCDM and SWOT. 2. Lack of an integrated model for selecting organization strategies and alternative strategies due to organization strategic position. 3. In respect of shared resource of implementation and operation of strategies, lack of the framework to assess the interaction of strategies because of their budget requirement. 4. Lack of formulating a framework for the effective assessment of organization's unselected possible strategies interaction on the prioritization pocess of selected strategies. SIM is a developed form of classic SWOT analysis. Like classic SWOT analysis and strategies selection process, SIM determines company strategic position (see Fig 4). Additionally, with a formulated process, SIM algorithm contains the selection of the main strategies and the alternative strategies, and also it assess organizations unselected possible strategies interaction on the ranking of selected strategies (see phase 6.4).

In this paper, we proposed two procedures to compute the numerical intervals of DMs decisions in the calculation process of the interactions (see Fig 6 and Eq. 22, 23). As portrayed in (Fig 6), the numerical interval of $\left(\otimes G_{i j}=\left[G_{i j}, \overline{G_{i j}}\right]\right)$ is calculated in accordance with the lowest value of the lower bounds and the highest value of the upper bounds in the decision making process as the $\left(G_{i j}\right)$ and $\left(\overline{G_{i j}}\right)$ respectively. In addition, two equations of (Eq 22,23) are presented for calculation of the mentioned interval. Furthermore, to compare between two grey numbers, this paper introduced an equation (see Eq 27), called grey importance value (GIV). Xie and Liu (2010), Cakır (2013), and Kong (2015) proposed other equations to compare two grey numbers.

SIM is a reliable approach for the evaluation, selection, and prioritization of the organizations strategies. Traditional SWOT analysis and SIM follows the same algorithm, while SIM proposes alternative strategies due to the uncertainty of the organization environment based on each four strategic positions. In addition, SIM offers a ranking process in accordance with the highest impact of each strategy on each other. Furthermore, SIM possesses advantages of AHP, ANP and other applied MCDM techniques in SWOT analysis. SIM structure is based on the comparison of impact of each strategy on each other by employing the entropy method to calculate the coefficient of alternative in a standard MCDM problem structure.

\section{Future Work}

The SIM flexible algorithm has a great potential to develop and integrate with MCDM methodologies. The SIM philosophy can be applied in many decision-making problems such as suppliers evaluation and selection, facility location selection, material selection problems and so on. Implementation of SIM in the fuzzy environment would be our first proposition for the future work. as it mentioned in the paper, the is proposed SIM algorithm is based on the grey numbers to handle the uncertainty of organizations environment. Like grey systems theory, fuzzy systems theory offers solutions for the uncertainty of environment. We also suggest integration of MCDM methods with SIM to rank the alternative strategies and integration with AHP, ANP, and BWM due to their hierarchy comparison structures. As the coefficient of alternatives, VI philosophy can be utilized to make a bridge between two irrelevance decision-making matrices. For instance, in the cases of evaluation and selection of suppliers, material selection, market segmentation, and market selection in line with the organizations strategies for making a strategic decision. Moreover, employing VI policy for computation of the attributes weights in the decision matrix, and using VI philosophy in the group decision-making can be considered as an interesting topic for the future research. GIV is a transferring method of grey numbers to the white numbers. Not only it can be used in grey systems applications, but also we suggest the development of other forms of GIV. In the Delphi panel, we used weights of decision makers. This policy can be developed in the group decision-making work.

\footnotetext{
References

1. Abdel-Basset, M., Mohamed, M. and Smarandache, F., 2018. An Extension of Neutrosophic AHP-SWOT Analysis for Strategic Planning and Decision-Making. Symmetry, 10(4), p.116.

2. ABZARI, M., BALOUEI, J.H., KHAZAEI, P.J. and POOR, M.K.M., 2013. EVALUATION OF THE PERFORMANCE OF GOVERNMENT DEPARTMENTS USING DEA AND SWOT MODELS AND STRUCTURAL EQUATIONS AND STRATEGIES TO PROMOTE EFFECTIVE STRATEGIC.

3. Alptekin, N., 2013. Integration of SWOT analysis and TOPSIS method in strategic decision making process. The Macrotheme Review, 2(7), pp.1-8.

4. Amin, S.H., Razmi, J. and Zhang, G., 2011. Supplier selection and order allocation based on fuzzy SWOT analysis and fuzzy linear programming. Expert Systems with Applications, 38(1), pp.334-342.

. Arslan, O. and Turan, O., 2009. Analytical investigation of marine casualties at the Strait of Istanbul with SWOT-AHP method. Maritime Policy \& Management, 36(2), pp.131-145.

6. Azimi, R., Yazdani-Chamzini, A., Fouladgar, M.M., Zavadskas, E.K. and Basiri, M.H., 2011. Ranking the strategies of mining sector through ANP and TOPSIS in a SWOT framework. Journal of Business Economics and Management, 12(4), pp.670-689.

7. Brown, S.W. and Swartz, T.A., 1989. A gap analysis of professional service quality. The Journal of Marketing, pp.92-98.

7. Cakir, O., 2013. On visualizing the number comparison scheme in grey extent analysis. Kybernetes, 42(1), pp.94-105.

9. Catron, J., Stainback, G.A., Dwivedi, P. and Lhotka, J.M., 2013. Bioenergy development in Kentucky: A SWOT-ANP analysis. Forest Policy and Economics, 28 , pp.38-43.

10. Çelik, A., Metin, İ. and Çelik, M., 2012. Taking a photo of Turkish fishery sector: A swot analysis. Procedia-Social and Behavioral Sciences, 58, pp.1515-1524.

11. Chen, F.P., 2013. Hebei Home Textile Industry Cluster Optimization Research Based on SWOT Analysis of Entropy Fuzzy Comprehensive Evaluation. In Advanced Materials Research (Vol. 627, pp. 601-604). Trans Tech Publications.

12. Choi, J.H., 2014. A SWOT based ANP Application for Strategy Development to enter Overseas Water Market. Journal of The Korean Society of Civil Engineers, 34(1), pp.305-316.

13. Das Adhikary, D., Kumar Bose, G., Bose, D. and Mitra, S., 2014. Multi criteria FMECA for coal-fired thermal power plants using COPRAS-G. International Journal of Quality \& Reliability Management, 31(5), pp.601-614.Deng, J.-L. (1989), "Introduction to grey system theory", The Journal of Grey System, Vol. 1 No. 1, pp. 1-24.

14. David, M.E., David, F.R. and David, F.R., 2017. The quantitative strategic planning matrix: a new marketing tool. Journal of Strategic Marketing, 25(4), pp.342-352.

15. Deng, J.L., 1982. Control problems of grey systems. Sys. \& Contr. Lett., l(5), pp.288-294.

16. Deng, J.L., 1985. Fundamental methods of grey systems. Huazhoug University of Science and Technology, Wuhan, China.

17. Deng, J.L., 1990. A course on grey system theory. Huazhong University of Science and Technology Press, Wuhan.

18. Dyson, R.G., 2004. Strategic development and SWOT analysis at the University of Warwick. European journal of operational research, 152(3), pp.631-640.
} 
19. Ebonzo, A.D.M. and Liu, X., 2013. The use of axiomatic fuzzy set theory in AHP and TOPSIS methodology to determine strategies priorities by SWOT analysis. Quality \& Quantity, 47(5), pp.2671-2685.

20. Eslamipoor, R. and Sepehriar, A., 2014. Firm relocation as a potential solution for environment improvement using a SWOT-AHP hybrid method. Process safety and environmental protection, 92(3), pp.269-276.

21. Farnham, D., 1999. Managing in a business context. CIPD Publishing.

22. Fertel, C., Bahn, O., Vaillancourt, K. and Waaub, J.P., 2013. Canadian energy and climate policies: A SWOT analysis in search of federal/provincial coherence. Energy Policy, 63, pp.1139-1150.

23. Forghani, M.A. and Izadi, L., 2013. Contractor Selection Based on Swot Analysis with Vikor and Topsis Methods in Fuzzy Environment. World Applied Sciences Journal, 24(4), pp.540-549.

24. Ghorbani, M., Arabzad, S.M. and Bahrami, M., 2012. Implementing Shannon entropy, SWOT and mathematical programming for supplier selection and order allocation. International Journal of Supply Chain Management, 1(1), pp.43-47.

25. Ghorbani, M., Bahrami, M. and Arabzad, S.M., 2012. An integrated model for supplier selection and order allocation; using Shannon entropy, SWOT and linear programming. ProcediaSocial and Behavioral Sciences, $41, \mathrm{pp} .521-527$.

26. Ghorbani, M., Velayati, R. and Ghorbani, M.M., 2011, May. Using fuzzy TOPSIS to determine strategy priorities by SWOT analysis. In International Conference on Financial Management and Economics (Vol. 11, pp. 135-139).

27. Glaister, K.W. and Falshaw, J.R., 1999. Strategic planning: still going strong?. Long Range Planning, 32(1), pp.107-116.

28. Görener, A., 2012. Comparing AHP and ANP: An application of strategic decisions making in a manufacturing company. International Journal of Business and Social Science, 3(11).

29. Görener, A., Toker, K. and Ulucay, K., 2012. Application of combined SWOT and AHP: a case study for a manufacturing firm. Procedia-social and behavioral sciences, 58, pp.15251534 .

30. Grundy, T., 2006. Rethinking and reinventing Michael Porter's five forces model. Strategic Change, 15(5), pp.213-229.

31. HATAMI, M.A. and Saati, S., 2009. An application of fuzzy TOPSIS method in an SWOT analysis.

32. He, L. and Liao, D., 2012. Credit NGOs' sustainability in rural financial market: a SWOT analysis on DAYBANG. Humanomics, 28(3), pp.200-208.

33. Heidari, M., Ashari, H.A., Farahbakht, S. and Parvaresh, S., 2014. Using the Analytic Network Process (ANP) in a SWOT analysis for the development of tourism destination-case study: Kish Island. International Journal of Management, 5(6), pp.21-21.

34. Hejazi, S., \& Lak, E. 2014. Determining priorities of effective organizational strategies by ANP and SWOT models.

35. Helms, M.M., Rodríguez, M.A., de los Ríos, L. and Hargrave, W., 2011. Entrepreneurial potential in Argentina: a SWOT analysis. Competitiveness review: An international business journal, 2l(3), pp.269-287.

36. Jiancheng, F.Q.Q.F.C., 2011. Primary Research on the Development Strategy Chioce of Under-Forest Economy in Guangxi Based on SWOT-AHP [J]. Forestry Economics, 11, p.020.

37. Jiansheng, W.B.G., 1995. An Analytical SWOT Model of Marketing Strategies [J]. SYSTEMS ENGINEERING--THEORY \& PRACTICE, 12.

38. Kahraman, C., Demirel, N.C. and Demirel, T., 2007. Prioritization of e-Government strategies using a SWOT-AHP analysis: the case of Turkey. European Journal of Information Systems, 16(3), pp.284-298.

39. Kahraman, C., Demirel, N.Ç., Demirel, T. and Ateş, N.Y., 2008. A SWOT-AHP application using fuzzy concept: e-government in Turkey. In Fuzzy multi-criteria decision making(pp. 85-117). Springer, Boston, MA.

40. Kong, X., 2015, August. Comparison of interval grey numbers based on the Monte Carlo method. In Grey Systems and Intelligent Services (GSIS), 2015 IEEE International Conference on (pp. 86-90). IEEE.

41. Krzysztof, O. (2007). Strategia organizacji. W poszukiwaniu trwałej przewagi konkurencyjnej..

42. Kuo, M.H., Kushniruk, A. and Borycki, E., 2011. Can cloud computing benefit health services?-a SWOT analysis. Studies in health technology and informatics, 169, pp.379-383.

43. Kurttila, M., Pesonen, M., Kangas, J. and Kajanus, M., 2000. Utilizing the analytic hierarchy process (AHP) in SWOT analysis-a hybrid method and its application to a forestcertification case. Forest policy and economics, $1(1)$, pp.41-52.

44. Laurenza, M., Consolini, G., Storini, M. and Damiani, A., 2012. A Shannon entropy approach to the temporal evolution of SEP energy spectrum. Astrophysics and Space Sciences Transactions, 8(1), pp.19-24.

45. Learned, E. P. (1969). Business policy: Text and cases. RD Irwin.

46. Lee, S. and Walsh, P., 2011. SWOT and AHP hybrid model for sport marketing outsourcing using a case of intercollegiate sport. Sport Management Review, 14(4), pp.361-369.

47. Lee, Y.H., 2015. Navigating SWOT-FANP with GSM method to prioritize the strategic location. Technological and Economic Development of Economy, $21(1)$, pp.140-163.

48. Li, C.Z., Hong, J., Xue, F., Shen, G.Q., Xu, X. and Luo, L., 2016. SWOT analysis and Internet of Things-enabled platform for prefabrication housing production in Hong Kong. Habitat International, 57, pp.74-87.

49. Lichuan, G.U., Wang, C. and Liu, I., 2013. SWOT Analysis for planning development of Agricultural Logistics in Anhui Povince.

50. MA, S. H., ZHOU, W., \& WANG, Y. Q., 2009. Configuration of Traffic Modes Between Megacity and its Satellite City Based on SWOT and Entropy Weight Decision-making. Journal of Huazhong University of Science and Technology (Urban Science Edition), 2007.

51. Margles, S.W., Masozera, M., Rugyerinyange, L. and Kaplin, B.A., 2010. Participatory planning: Using SWOT-AHP analysis in buffer zone management planning. Journal of sustainable forestry, 29(6-8), pp.613-637.

52. Memon, M.S., Lee, Y.H. and Mari, S.I., 2015. Group multi-criteria supplier selection using combined grey systems theory and uncertainty theory. Expert Systems with Applications, 42(21), pp.7951-7959.

53. Mohamad, D., Afandi, N.S. and Kamis, N.H., 2015, October. Strategic planning decision making using fuzzy SWOT-TOPSIS with reliability factor. In AIP Conference Proceedings(Vol. 1682, No. 1, p. 030002). AIP Publishing.

54. Nagara, G., Lam, W.H., Lee, N.C.H., Othman, F. and Shaaban, M.G., 2015. Comparative SWOT analysis for water solutions in Asia and Africa. Water resources management, 29(1), pp.125-138.

55. Nejad, M.B., Pouyan, N. and Shojaee, M.R., 2011. Applying TOPSIS and QSPM methods in framework SWOT model: case study of the Iran's stock market. Australian Journal of Business and Management Research, 1(5), p.93.

56. Nejatbakhsh, Y. and Bahremand, S., 2015. Formulating, Evaluating and Prioritizing a Production Company Strategies using Hybrid FUZZY TOPSIS-SWOT Model (Case Study: Tehran PAK Dairy Company). Indian Journal of Science and Technology, 8(27).

57. Nikjoo, A.V. and Saeedpoor, M., 2014. An intuitionistic fuzzy DEMATEL methodology for prioritising the components of SWOT matrix in the Iranian insurance industry. International Journal of Operational Research, 20(4), pp.439-452.

58. Ostrega, A., De Felice, F. and Petrillo, A., 2011. ANP-SWOT approach to minimize environmental impacts due mining activities. In Proceedings of ISAHP 2011 Symposium, Italy.

59. Osuna, E.E. and Aranda, A., 2007. Combining SWOT and AHP techniques for strategic planning. Economic Journal. Instituto de Estudios Superiores de Administración (IESA) Avenida IESA, San Bernardino, Caracas-Venezuela.

60. Ozkok, M. and Cebi, S., 2014. A fuzzy based assessment method for comparison of ship launching methods. Journal of Intelligent \& Fuzzy Systems, 26(2), pp.781-791.

61. Panagiotou, G., 2003. Bringing SWOT into focus. Business strategy review, 14(2), pp.8-10.

62. Párraga, M.M., Gonzalez-Cancelas, N. and Soler-Flores, F., 2014. DELPHI-SWOT tools used in strategic planning of the Port of Manta. Procedia-Social and Behavioral Sciences, 162, pp. $129-138$.

63. RAHNAMAEI, M., POORAHMAD, A. and ASHRAFI, Y., 2011. APPRAISING THE CAPABILITIES OF MARAGHE URBAN DEVELOPMENT BY USING COMPOUND MODEL SWOT-ANP.

64. Sachdeva, A., Kumar, D. and Kumar, P., 2009. Multi-factor failure mode critically analysis using TOPSIS.

65. Saeedpoor, M., Kazzazi, A., Hadjarian Kashani, M. and Vafadar Nikjoo, A., 2012. Ranking the Elements of SWOT matrix with the Approach of Combining Gray Theory and DEMATEL Technique. In Proc. of the 8th International Industrial Engineering Conference (IIEC), Tehran, Iran.

66. Şeker, S.. and Özgürler, M., 2012. Analysis of the Turkish consumer electronics firm using SWOT-AHP method. Procedia-social and behavioral sciences, 58 , pp.1544-1554.

67. Sevkli, M., Oztekin, A., Uysal, O., Torlak, G., Turkyilmaz, A. and Delen, D., 2012. Development of a fuzzy ANP based SWOT analysis for the airline industry in Turkey. Expert systems with Applications, 39(1), pp.14-24.

68. Shahabi, R.S., Basiri, M.H., Kahag, M.R. and Zonouzi, S.A., 2014. An ANP-SWOT approach for interdependency analysis and prioritizing the Iran' s steel scrap industry strategies. Resources Policy, 42, pp.18-26.

69. Shakerian, H., Dehnavi, H.D. and Ghanad, S.B., 2016. The implementation of the hybrid model SWOT-TOPSIS by fuzzy approach to evaluate and rank the human resources and business strategies in organizations (case study: road and urban development organization in Yazd). Procedia-Social and Behavioral Sciences, 230, pp.307-316.

70. SHAMSODDINI, A. and AMIRI, F.M., 2015. Evaluation the Effective Factors on Rural Land Use Management in Mammasani County (by Utilizing Topsis Model and Swot)

71. Shannon, C.E., 2001. A mathematical theory of communication. ACM SIGMOBILE mobile computing and communications review, 5(1), pp.3-55.

72. Shi, X., 2016. The future of ASEAN energy mix: A SWOT analysis. Renewable and sustainable energy reviews, 53, pp.672-680.

73. Shojaei, M., Abbaszade, S. and Aghaei, S.S., 2013. Using Analytical Network Process (ANP) Method to Proritize Strategies Resulted from SWOT Matrix. Interdisciplinary Journal of Contemporary Research in Business, 4(9), pp.603-618.

74. Shojaei, M.R., Taheri, N.S. and Mighani, M.A., 2010. Strategic planning for a food Industry Equipment manufacturing factory, Using SWOT Analysis, QSPM, and MAUT models.

75. Shrestha, R.K., Alavalapati, J.R. and Kalmbacher, R.S., 2004. Exploring the potential for silvopasture adoption in south-central Florida: an application of SWOT-AHP method. Agricultural Systems, $81(3)$, pp.185-199. 
76. Stainback, G.A., Masozera, M., Mukuralinda, A. and Dwivedi, P., 2012. Smallholder agroforestry in Rwanda: A SWOT-AHP analysis. Small-scale Forestry, 11(3), pp.285-300.

77. Suh, J., 2014. Theory and reality of integrated rice-duck farming in Asian developing countries: A systematic review and SWOT analysis. Agricultural Systems, 125 , pp.74-81.

78. Syazwan Ab Talib, M. and Bakar Abdul Hamid, A., 2014. Halal logistics in Malaysia: a SWOT analysis. Journal of Islamic Marketing, 5(3), pp.322-343.

79. Szulecka, J. and Zalazar, E.M., 2017. Forest plantations in Paraguay: Historical developments and a critical diagnosis in a SWOT-AHP framework. Land Use Policy, 60, pp.384-394.

80. Szulecka, J. and Zalazar, E.M., 2017. Forest plantations in Paraguay: Historical developments and a critical diagnosis in a SWOT-AHP framework. Land Use Policy, 60, pp.384-394.

81. Tahernejad, M.M., Khalokakaie, R. and Ataei, M., 2013. Determining proper strategies for Iran's dimensional stone mines: a SWOT-AHP analysis. Arabian Journal of Geosciences, 6(1), pp.129-139.

82. Taleai, M., Mansourian, A. and Sharifi, A., 2009. Surveying general prospects and challenges of GIS implementation in developing countries: a SWOT-AHP approach. Journal of Geographical Systems, 11(3), pp.291-310.

83. Tang, L.C., Atkinson, B. and Zou, R.R., 2012. An entropy-based SWOT evaluation process of critical success factors for international market entry: A case study of a medium-sized consulting company. Construction Management and Economics, 30(10), pp.821-834.

84. Tavana, M., Zareinejad, M., Di Caprio, D. and Kaviani, M.A., 2016. An integrated intuitionistic fuzzy AHP and SWOT method for outsourcing reverse logistics. Applied Soft Computing, 40, pp.544-557.

85. Thira, W. and Patarawan, W., 2012. Assessment of prospective physician characteristics by SWOT analysis. The Malaysian journal of medical sciences: MJMS, $19(1)$, p.60.

86. Toklu, M.C., Erdem, M.B. and Taşkın, H., 2016. A fuzzy sequential model for realization of strategic planning in manufacturing firms. Computers \& Industrial Engineering, 102, pp.512-519.

87. Triantaphyllou, E., 2000. Multi-criteria decision making methods. In Multi-criteria Decision Making Methods: A Comparative Study. pp. 5-21. Springer US

88. Tseng, M.L., 2009. A causal and effect decision making model of service quality expectation using grey-fuzzy DEMATEL approach. Expert systems with applications, 36(4), pp.77387748 .

89. Tsitsiloni, M., Grigoroudis, E. and Zopounidis, C., 2013. Service quality evaluation in the tourism industry: A SWOT analysis approach. In Optimization theory, decision making, and Tsitsiloni, M., Grigoroudis, E. and Zopounidis, C., 2013. Service quality eval
operations research applications (pp. 249-266). Springer, New York, NY.

90. Van Durme, T., Macq, J., Anthierens, S., Symons, L., Schmitz, O., Paulus, D., Van den Heede, K. and Remmen, R., 2014. Stakeholders' perception on the organization of chronic care: a SWOT analysis to draft avenues for health care reforms. BMC health services research, 14(1), p.179.

91. Verraes, C., Uyttendaele, M., Clinquart, A., Daube, G., Sindic, M., Berkvens, D. and Herman, L., 2015. Microbiological safety and quality aspects of the short supply chain: SWOT analysis of the Belgian case study. British Food Journal, 117(9), pp.2250-2264.

92. Wang, M., Liu, S., Wang, S. and Lai, K.K., 2010. A weighted product method for bidding strategies in multi-attribute auctions. Journal of Systems Science and Complexity, 23(1), pp.194-208.

93. Wang, W., Du, X., \& Lu, Z., 2011, June. Analysis of the cumulative effect of pollution in the atmospheric environment management based on the method of ANP embedding into SWOT. In Remote Sensing, Environment and Transportation Engineering (RSETE), 2011 International Conference on, pp. 65-68. IEEE.

94. Wang, X.P., Zhang, J. and Yang, T., 2014. Hybrid SWOT approach for strategic planning and formulation in china worldwide express mail service. Journal of applied research and technology, 12(2), pp.230-238.

95. Wasike, C.B., Magothe, T.M., Kahi, A.K. and Peters, K.J., 2011. Factors that influence the efficiency of beef and dairy cattle recording system in Kenya: A SWOT-AHP analysis. Tropical animal health and production, 43(1), pp.141-152

96. WICKRAMASINGHE, V.S.K. and Takano, S.E., 2009. Application of Combined SWOT and Analytic Hierarchy Process (AHP) for Tourism Revival Strategic Marketing Planning. In Proceedings of the Eastern Asia Society for Transportation Studies Vol. 7 (The 8th International Conference of Eastern Asia Society for Transportation Studies, 2009) (pp. 189-189). Eastern Asia Society for Transportation Studies.

97. Xie, N.M. and Liu, S.F., 2010. Novel methods on comparing grey numbers. Applied Mathematical Modelling, 34(2), pp.415-423.

98. Xie, N.M. and Liu, S.F., 2010. Novel methods on comparing grey numbers. Applied Mathematical Modelling, 34(2), pp.415-423.

99. Xing, B. and Gao, W.J., 2015. A SWOT Analysis of Intelligent Products Enabled Complex Adaptive Logistics Systems. In Encyclopedia of Information Science and Technology, Third Edition (pp. 4970-4979). IGI Global.

100. Yan, J., Xia, F. and Bao, H.X., 2015. Strategic planning framework for land consolidation in China: a top-level design based on SWOT analysis. Habitat International, 48 , pp.46-54.

101. Yang-tian, Z., Wei-zhong, C., Yi-feng, D., Hong-sheng, Y. and Center, G.L.P., 2013. Exploration of Guangxi lightning protection enterprise development strategy based on the DEMATEL and SWOT method. Journal of Meteorological Research and Application, 4, p.020.

102. Ying, Y., 2010, May. SWOT-TOPSIS integration method for strategic decision. In E-Business and E-Government (ICEE), 2010 International Conference on (pp. 1575-1578). IEEE.

103. Yuan, Y., Zhang, Y., Di, L., Wu, G.G. and Yang, Z.X., 2015, August. Research on large supermarket fresh food supplier evaluation and selection based on SWOT-Entropy Weight Fuzzy Comprehensive model. In Advanced Mechatronic Systems (ICAMechS), 2015 International Conference on (pp. 15-19). IEEE.

104. Yüksel, İ. and Dagdeviren, M., 2007. Using the analytic network process (ANP) in a SWOT analysis-A case study for a textile firm. Information Sciences, 177(16), pp.3364-3382.

105. Yüksel, I., 2012. Developing a multi-criteria decision making model for PESTEL analysis. International Journal of Business and Management, 7(24), p.52.

106. Zadeh, L.A., 1965. Information and control. Fuzzy sets, 8(3), pp.338-353.

107. Zhang, Y. and Feng, L., 2013. Development assessment of leisure agriculture in Henan province of China based on SWOT-AHP method. Journal of Industrial Engineering and Management, 6(2), pp.642-656.

108. Zhao, S.Y., Yang, S., Liang, C. and Gu, D., 2016. Where is the way for rare earth industry of China: An analysis via ANP-SWOT approach. Resources Policy, 49, pp.349-357. 


\section{Figures}

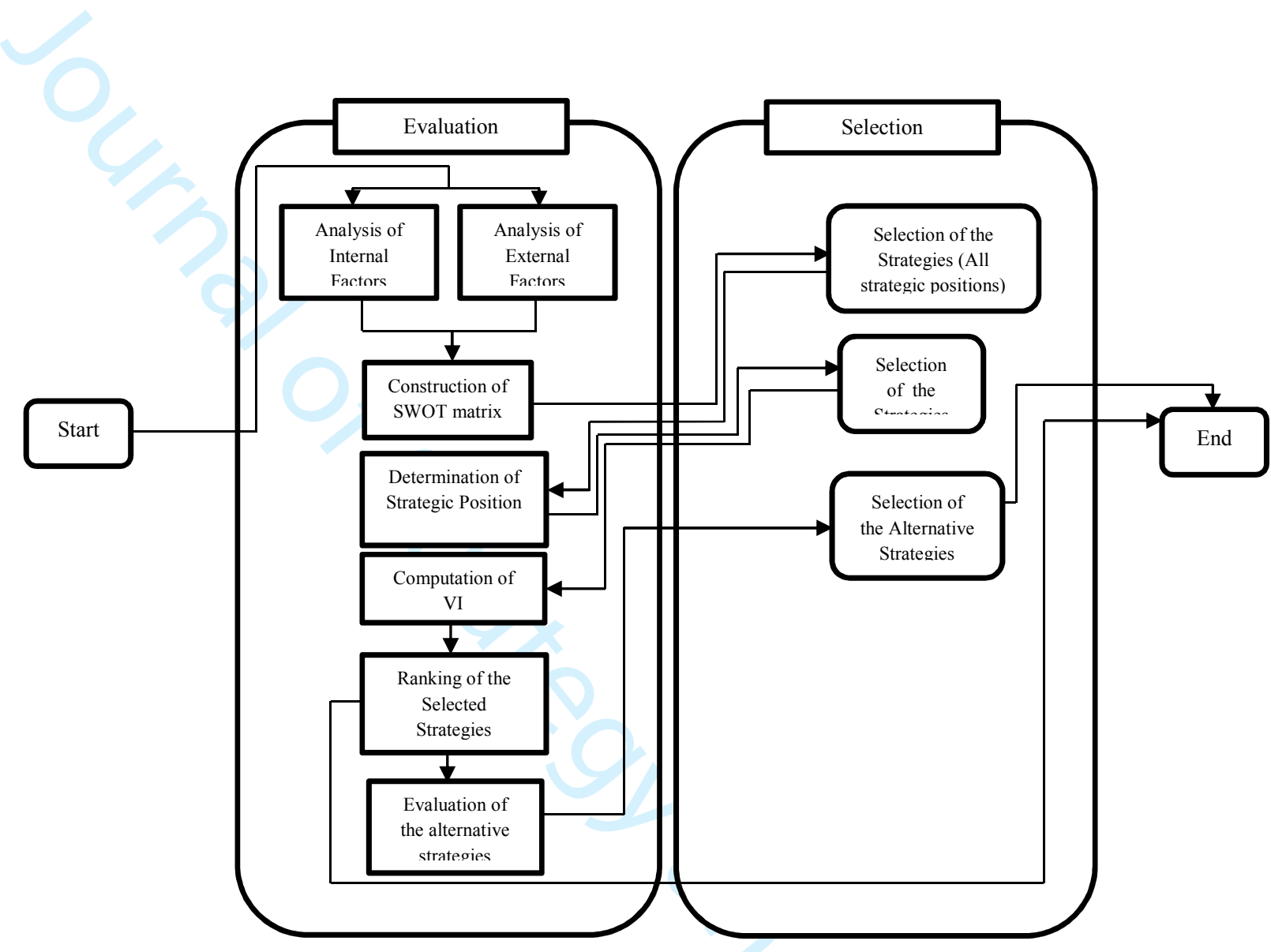

Fig 1. The Proposed methodology procedure workflow of SIM

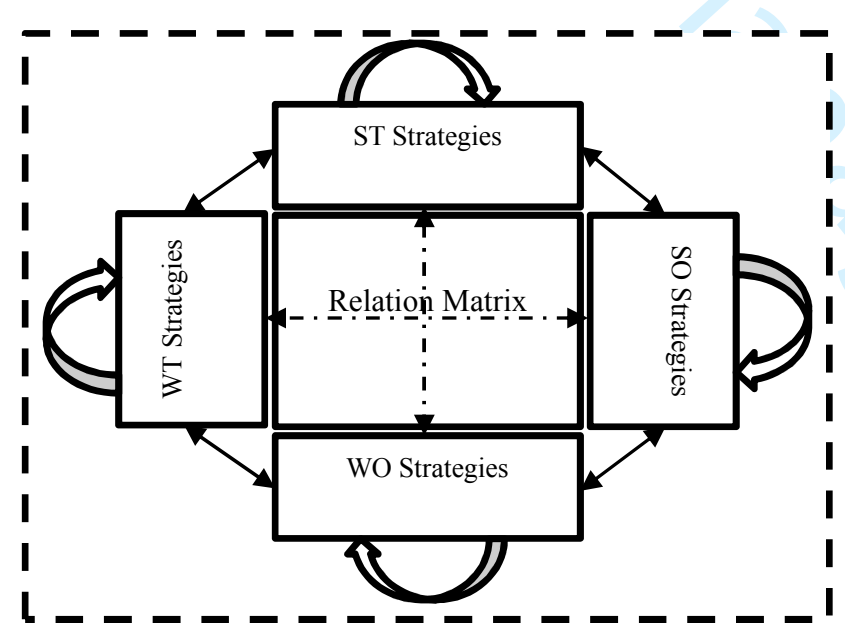

Fig 2. The Proposed Strategies Interaction Model (SIM) 


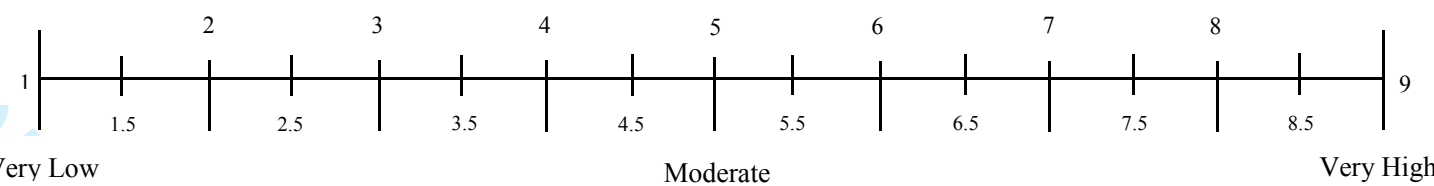

Fig 3. Numerical scale of weighting and rating; the scale includes three ranges of very low, moderate high and very high. Other groups of linguistic variables such as low, moderate low, high and moderate high have not been specified and DM chooses the numbers between very low, moderate and very high as his/her option.

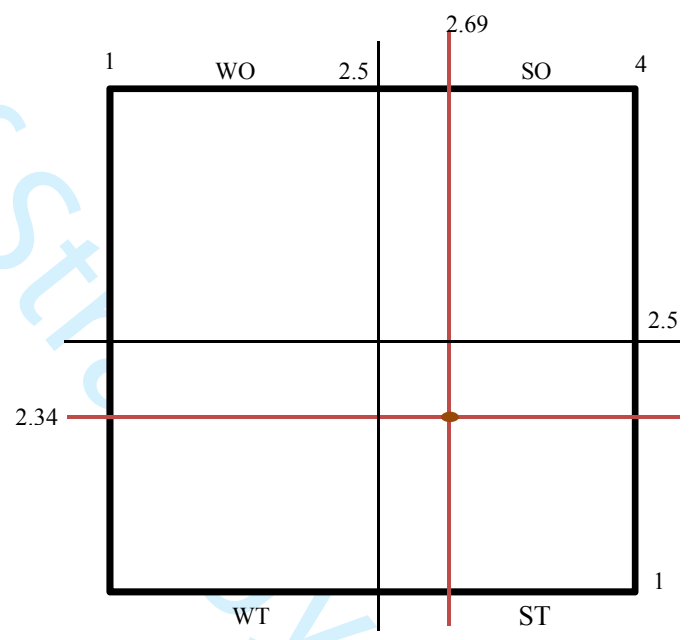

Fig 4. Graphical structure: determination of strategic position.

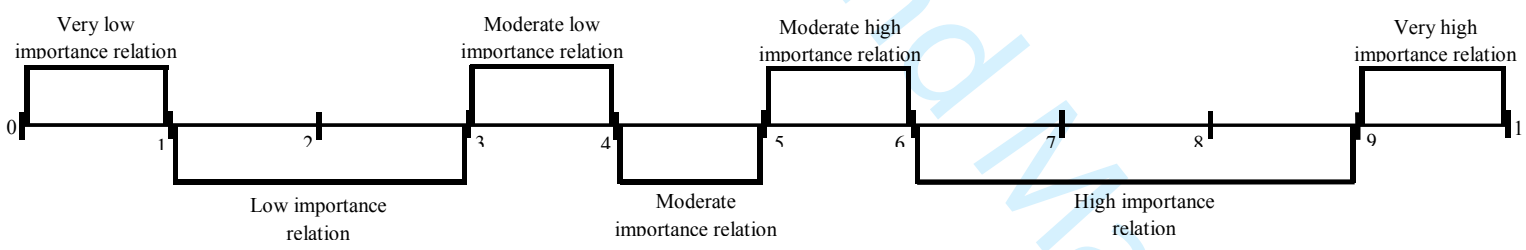

Fig 5. Numerical scale for relation matrix: linguistic variables and their corresponding numerical variables

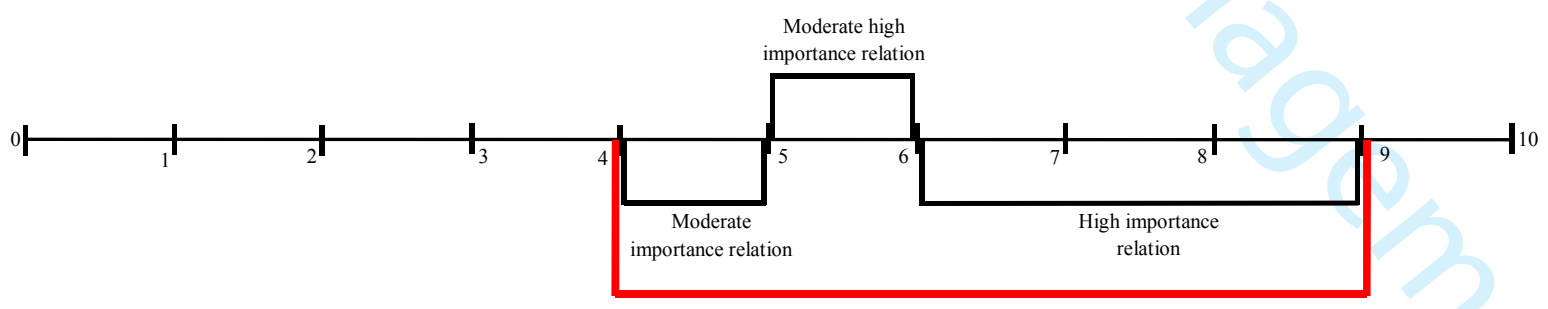

Fig 6. Graphical concept of the mentioned interval computation: for instance, let suppose DMs decisions are the intervals of $[4,5]$, $[5,6]$ and $[6,9]$, the right interval for computation of interaction is $[4,9]$ where the DMs decisions are between the lowest and the highes intervals (red line). 


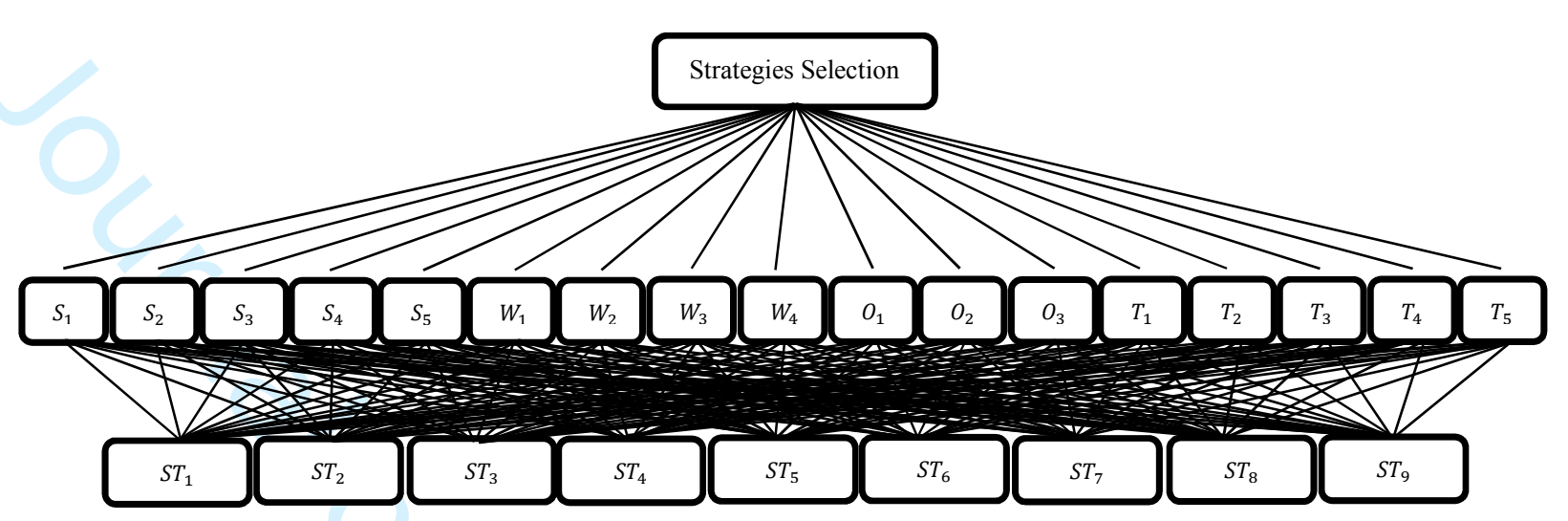

Fig 7. AHP structure: the case study strategies selection procedure

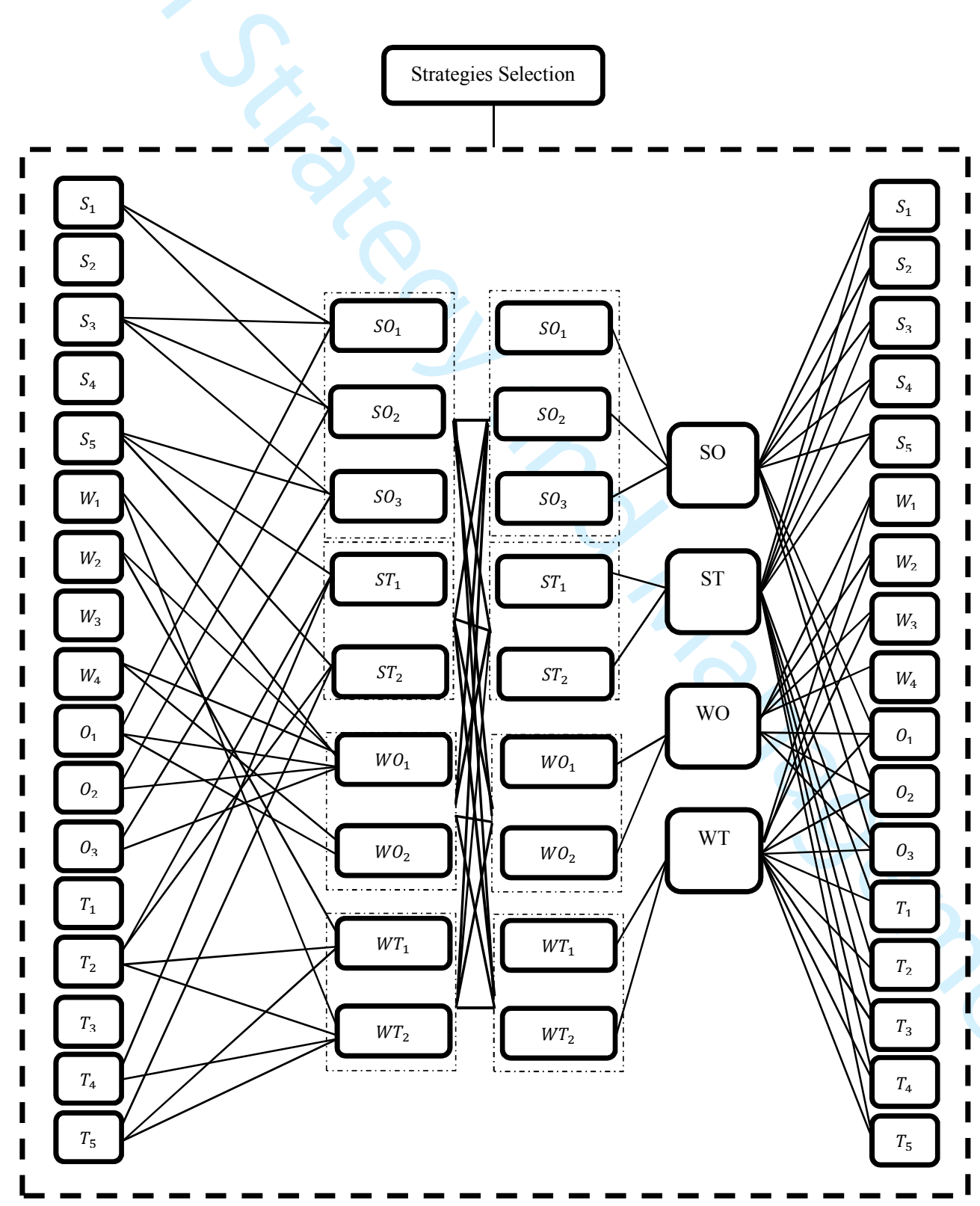


Fig 8. SIM structure: the case study strategies selection procedure 
Table 2

Review of the literature. Combination of MCDM methodologies with SWOT analysis

\begin{tabular}{llll}
\hline Review of the literature. Combination of MCDM methodologies with SWOT analysis & \\
\hline Technique & Author(s) \& Year & Application \& Specific Area \\
\hline TOPSIS & Azimi, Yazdani-Chamzini, Fouladgar, Zavadskas and Basiri & 2011 & Mining sector \\
& Ying & 2010 & Integrated model for strategic decision making \\
& Ghorbani, Velayati, Ghorbani & 2011 & Financial and economics (prioritization of strategies) \\
Nejad, Pouyan and Shojaee & 2011 & Iran's stock market \\
& Hatami Marbini and Saati & 2009 & Cosmetics organization \\
& 2013 & Furniture firm \\
& Alptekin & 2014 & Shipyard production system \\
& Ozkok and Cebi & 2015 & Environmental (rural land ) \\
SHAMSODDINI and AMIRI & 2015 & Local authority in the east coast of Malaysia
\end{tabular}

\section{Tables}

Table 1

Literature review of application of SWOT

\begin{tabular}{|c|c|c|c|c|c|c|c|}
\hline Topic & Author & Year & Focus & Topic & Author & Year & Focus \\
\hline \multirow[t]{2}{*}{$\begin{array}{l}\text { Environment and } \\
\text { energy }\end{array}$} & $\begin{array}{c}\text { Szulecka } \\
\text { and Zalazar }\end{array}$ & 2017 & $\begin{array}{l}\text { With an AHP-SWOT analysis combined } \\
\text { method, they found } 36 \text { factors that } \\
\text { influence plantation establishment in } \\
\text { rainy forest of Paraguay }\end{array}$ & logistic & $\begin{array}{c}\text { Tavana et } \\
\text { al }\end{array}$ & 2016 & $\begin{array}{l}\text { In a fuzzy environment, with a hybrid } \\
\text { method of Fuzzy AHP and SWOT } \\
\text { analysis, this study evaluated strategic } \\
\text { factor in an outsourcing reverse logistics. }\end{array}$ \\
\hline & Shi & 2016 & $\begin{array}{l}\text { This study used SWOT to review } \\
\text { internal and external factors of green } \\
\text { energy using in Association of Southeast } \\
\text { Asian Nations (ASEAN) }\end{array}$ & & & & \\
\hline \multirow[t]{4}{*}{$\begin{array}{l}\text { Agriculture and } \\
\quad \text { foods }\end{array}$} & $\begin{array}{c}\text { Syazwan \& } \\
\text { Bakar }\end{array}$ & 2014 & $\begin{array}{l}\text { To identify SWOT in the Halal logistics } \\
\text { environment, this study focused Halal } \\
\text { logistics industry in Malaysia. }\end{array}$ & $\begin{array}{l}\text { supply chain } \\
\text { and services }\end{array}$ & $\begin{array}{l}\text { Verraes et } \\
\quad \text { al }\end{array}$ & 2015 & $\begin{array}{l}\text { With a comparative analysis of } \\
\text { microbiological quality and safety } \\
\text { aspects, this research compared short } \\
\text { food supply chain and conventional food } \\
\text { supply chain in Belgium through SWOT } \\
\text { analysis. }\end{array}$ \\
\hline & Suh & 2014 & $\begin{array}{l}\text { With using expert elicitation method, } \\
\text { this study used SWOT analysis for case } \\
\text { of the integrated rice-duck farming in } \\
\text { South Korea, Malaysia and Vietnam. }\end{array}$ & & 冫 & & \\
\hline & Çelik et al & 2013 & $\begin{array}{l}\text { This study deal with SWOT analysis to } \\
\text { find strengths and weaknesses, and } \\
\text { threats and opportunities of the Turkish } \\
\text { fishery sector through a workshop with } \\
\text { the fishery companies. }\end{array}$ & health & $\begin{array}{l}\text { Van Durme } \\
\quad \text { et al }\end{array}$ & 2014 & $\begin{array}{l}\text { This study proposed a methodoogy for } \\
\text { identification of problematic domains in } \\
\text { the health system for people living with } \\
\text { chronic conditions by SWOT analysis } \\
\text { through thematic analysis of the } \\
\text { transcripts. }\end{array}$ \\
\hline & & & & & Kuo et al & 2011 & $\begin{array}{l}\text { This research evaluated the feasibility of } \\
\text { adopting cloud computing model in } \\
\text { healthcare by SWOT analysis. }\end{array}$ \\
\hline \multirow[t]{3}{*}{ Production } & Li et al & 2016 & $\begin{array}{l}\text { With and data collection from literature } \\
\text { review, prefabrication-related } \\
\text { regulations, interviews with experts, and } \\
\text { government reports, this study deal with } \\
\text { SWOT analysis to facilitate a more in- } \\
\text { depth understanding of the management } \\
\text { of prefabrication housing production } \\
\text { development status in housing } \\
\text { production in Hong Kong. }\end{array}$ & & & & \\
\hline & $\begin{array}{c}\text { Nagara et } \\
\text { al }\end{array}$ & 2015 & $\begin{array}{l}\text { This paper applies SWOT (strengths, } \\
\text { weaknesses, opportunities and threats) } \\
\text { analysis to examine the suitability of } \\
\text { virtual water trading, desalination, } \\
\text { groundwater extraction and wastewater } \\
\text { reuse as alternative water solutions to } \\
\text { alleviate water scarcity. }\end{array}$ & $\begin{array}{c}\text { Organization } \\
\text { and } \\
\text { Marketing }\end{array}$ & $\begin{array}{l}\text { Abdel- } \\
\text { Basset }\end{array}$ & 2018 & $\begin{array}{l}\text { This paper employed an AHP-SWOT } \\
\text { analysis approach in neutrosophic } \\
\text { environment with the case of Starbucks } \\
\text { Company. }\end{array}$ \\
\hline & & & & & David et al & 2017 & $\begin{array}{l}\text { This paper discussed about QSPM } \\
\text { application in marketing }\end{array}$ \\
\hline
\end{tabular}


Table 3

Synthesis of SWOT analysis

\begin{tabular}{|c|c|c|c|c|c|c|c|}
\hline \multicolumn{2}{|c|}{ Strengths } & \multicolumn{2}{|c|}{ Weaknesses } & \multicolumn{2}{|c|}{ Opportunities } & \multicolumn{2}{|c|}{ Threats } \\
\hline $\mathrm{S}_{1}$ & High quality products & $\mathrm{W}_{1}$ & Market research & $\mathrm{O}_{1}$ & Untapped domestic markets & $\mathrm{T}_{1}$ & $\begin{array}{l}\text { Fluctuations in the economic and } \\
\text { governmental laws }\end{array}$ \\
\hline $\mathrm{S}_{2}$ & $\begin{array}{l}\text { Usage of high quality raw } \\
\text { materials }\end{array}$ & $\mathrm{W}_{2}$ & Branding & $\mathrm{O}_{2}$ & $\begin{array}{l}\text { Untapped markets for } \\
\text { exportation }\end{array}$ & $\mathrm{T}_{2}$ & Strong competitors (newcomers) \\
\hline $\mathrm{S}_{3}$ & Innovation and variety & $\mathrm{W}_{3}$ & ERP Software & $\mathrm{O}_{3}$ & $\begin{array}{l}\text { orientation of society healthy } \\
\text { products }\end{array}$ & $\mathrm{T}_{3}$ & $\begin{array}{l}\text { Fluctuations in international political } \\
\text { relations }\end{array}$ \\
\hline $\mathrm{S}_{4}$ & $\begin{array}{l}\text { Fiscal discipline (revenues, } \\
\text { expenses and obligations) }\end{array}$ & $\mathrm{W}_{4}$ & Distribution & & & $\mathrm{T}_{4}$ & $\begin{array}{l}\text { Fluctuations in the purchasing power } \\
\text { of the people }\end{array}$ \\
\hline $\mathrm{S}_{5}$ & Flexible production & & & & & $\mathrm{T}_{5}$ & SUBSTITUTE GOODS \\
\hline
\end{tabular}

Contractor Selection

Human Resource

Iranian dairy Company

Forest

Agriculture (South central florida)

Tourism Marketing (Sri Lanka)

Marketing strategies

Examination of sport marketing outsourcing decision-making

Forest economy (China, Yichang City in Hubei Province)

Information systems ( Turkey, e-government

Manufacturing (Turkey)

Medical service (VWL Medical Services)

Supply Chain

E-Government (Turkey)

Marketing ( consumer - Turkish electronics firm)

Maritime (Turkey)

Geographical systems ( implementation of GIS in developing country)

Cattle recording systems (Animal Husbandry in Kenya)

Geoscience (Mining; Iranian dimensional stone mines)

Environmental ( relocation of the firm for air pollution)

Forest

Forest (Agroforestry - Rwanda)

Applied AFS (axiomatic fuzzy set theory) and implemented in the case of (Yuksel \&deviren.2007)

Textile firm

Steel scrap industry strategies

Airline Industry

Mining sector

Environmental (the cumulative effect of pollution in the atmospheric environment)

Bio energy (Kentucky)

Compared Application of AHP and ANP

Environmental and mining

Environmental management (Slovenia)

Resource (China)

Medical equipment's industry

Tourism destination (Kish Island)

Medical equipment producer industry

Water Market

Urban management ( Iran, Maraghe)

Location selection for a second tier city in China

Supply Chain

International marketing (UK consulting company)

Textile Industry

Food and Supply chain

Traffic

Supply Chain

Insurance industry (Iran)

A combination of Grey theory and DEMATEL

lightning protection and disaster mitigation situation

Governmental

Supply chain

Supply Chain

Supply Chain

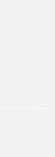


Table 4

Integration of $\left(W D M s_{j}\right)$ and $(W D M s)$ of importance weight. "WDMs" has been calculated by sum of simple averages (SA) of each expert group's decisions.

\begin{tabular}{|c|c|c|c|c|c|c|c|c|}
\hline & \multicolumn{4}{|c|}{ Theoretical Experts } & \multicolumn{4}{|c|}{ Practical Experts } \\
\hline & $C_{1}$ & $C_{2}$ & $C_{3}$ & $V P_{1}$ & $V P_{2}$ & $V P_{3}$ & $V P_{4}$ & $V P_{5}$ \\
\hline$W D M s_{1} j$ & 0.1839 & 0.0847 & 0.1826 & 0.1860 & 0.0577 & 0.1294 & 0.0901 & 0.0856 \\
\hline$W D M s_{1} j$ & 0.1133 & 0.1497 & 0.1025 & 0.1133 & 0.1663 & 0.1025 & 0.1497 & 0.1025 \\
\hline$W D M s_{2} j$ & 0.0056 & 0.9649 & 0.0018 & 0.0083 & 0.0069 & 0.0052 & 0.0051 & 0.0022 \\
\hline$W D M s_{2} j$ & 0.1353 & 0.1562 & 0.1562 & 0.1353 & 0.1219 & 0.0881 & 0.1036 & 0.1036 \\
\hline$S A_{W D M s_{j}}$ & 0.110 & 0.339 & 0.111 & 0.111 & 0.088 & 0.081 & 0.087 & 0.073 \\
\hline WDMs & \multicolumn{4}{|c|}{0.670} & \multicolumn{4}{|c|}{0.330} \\
\hline
\end{tabular}

Table 5

Scores of internal factors where the weights of importance and rankings are the SA of DMs in each experts group.

\begin{tabular}{|c|c|c|c|c|c|c|c|c|c|c|}
\hline & & \multicolumn{3}{|c|}{ Theoretical experts } & \multicolumn{5}{|c|}{ Practical experts } & \multirow[b]{2}{*}{ score } \\
\hline & & $W D M s_{1}$ & $W_{1}$ & $N$ & Rank & $W D M s_{2}$ & $W_{2}$ & $N$ & rank & \\
\hline \multirow{5}{*}{ 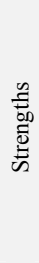 } & High quality products & 0.670 & 8.50 & 0.116 & 3.75 & 0.330 & 8.88 & 0.118 & 4.00 & 0.45 \\
\hline & Usage of high quality raw materials & 0.670 & 7.50 & 0.103 & 3.00 & 0.330 & 8.00 & 0.107 & 3.25 & 0.33 \\
\hline & Innovation and variety & 0.670 & 8.25 & 0.113 & 4.00 & 0.330 & 8.38 & 0.112 & 3.75 & 0.43 \\
\hline & $\begin{array}{l}\text { Fiscal discipline ((revenues, } \\
\text { expenses and obligations)) }\end{array}$ & 0.670 & 8.63 & 0.118 & 3.75 & 0.330 & 8.50 & 0.113 & 3.25 & 0.40 \\
\hline & Flexible production & 0.670 & 7.25 & 0.099 & 3.00 & 0.330 & 7.88 & 0.105 & 3.25 & 0.32 \\
\hline \multirow{5}{*}{  } & Market research & 0.670 & 8.50 & 0.116 & 2.00 & 0.330 & 8.25 & 0.110 & 2.00 & 0.23 \\
\hline & Branding & 0.670 & 8.38 & 0.115 & 1.75 & 0.330 & 8.50 & 0.113 & 1.50 & 0.19 \\
\hline & ERP Software & 0.670 & 7.50 & 0.103 & 1.00 & 0.330 & 7.88 & 0.105 & 1.25 & 0.12 \\
\hline & Distribution & 0.670 & 8.63 & 0.118 & 2.00 & 0.330 & 8.75 & 0.117 & 1.75 & 0.22 \\
\hline & & & & & & & & \multicolumn{2}{|c|}{ Total Score } & 2.69 \\
\hline
\end{tabular}

Table 6

Scores of external factors where the weights of importance and rankings are the SA of DMs in each experts group.

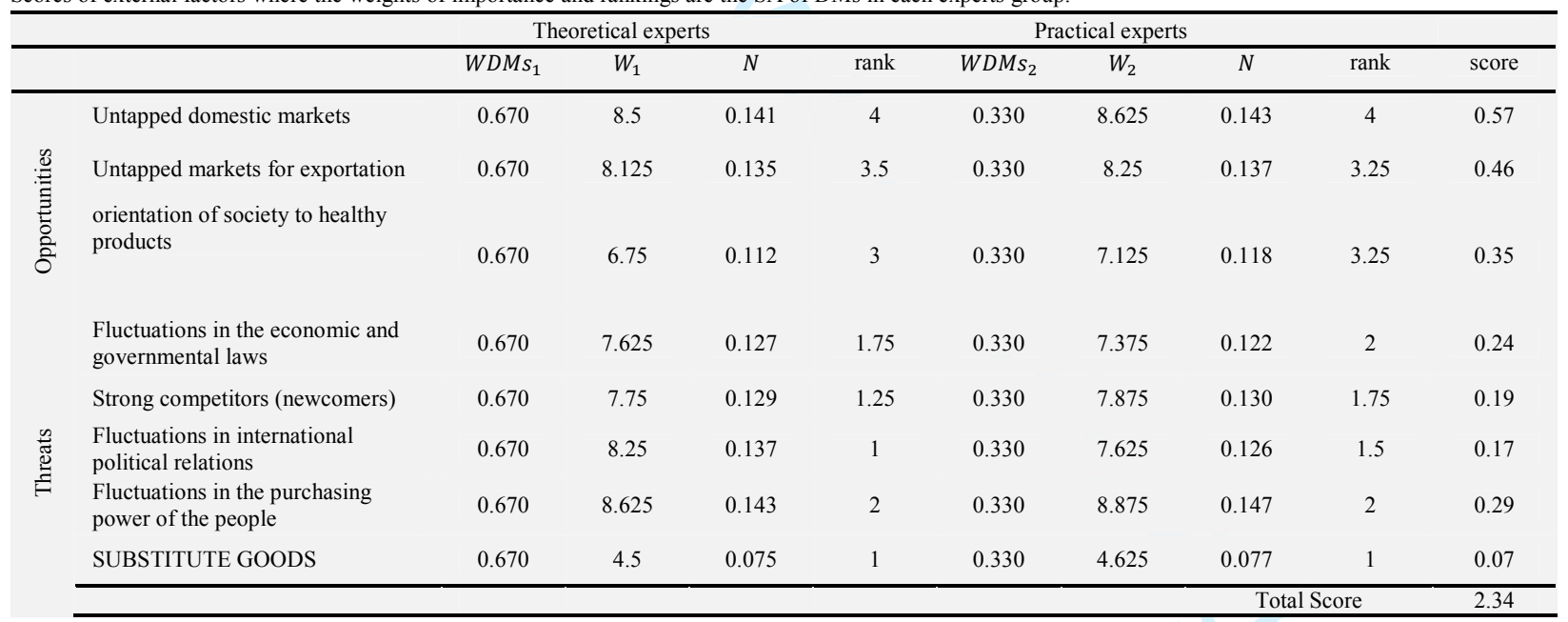

Table 7

Computation of $V I$

\begin{tabular}{|c|c|c|c|c|c|c|c|c|c|c|c|c|c|c|c|c|c|c|}
\hline & \multicolumn{2}{|c|}{$\overline{S O_{1}}$} & \multicolumn{2}{|c|}{$\mathrm{SO}_{2}$} & \multicolumn{2}{|c|}{$\mathrm{SO}_{3}$} & \multicolumn{2}{|c|}{$S T_{1}$} & \multicolumn{2}{|c|}{$S T_{2}$} & \multicolumn{2}{|c|}{$W O_{1}$} & \multicolumn{2}{|c|}{$\mathrm{WO}_{2}$} & \multicolumn{2}{|c|}{$W T_{1}$} & \multicolumn{2}{|c|}{$W T_{2}$} \\
\hline & \multicolumn{6}{|c|}{ Score } & \multicolumn{4}{|c|}{ Score } & \multicolumn{4}{|c|}{ Score } & \multicolumn{4}{|c|}{ Score } \\
\hline & \multicolumn{2}{|c|}{1.45} & \multicolumn{2}{|c|}{1.34} & \multirow{2}{*}{\multicolumn{2}{|c|}{1.21}} & \multicolumn{4}{|c|}{0.58} & \multirow{2}{*}{\multicolumn{4}{|c|}{2.02}} & \multicolumn{2}{|c|}{0.62} & \multicolumn{2}{|c|}{0.78} \\
\hline & \multicolumn{4}{|c|}{$\left(\lambda_{j}\right)$} & & & \multicolumn{4}{|c|}{$\left(\lambda_{j}\right)$} & & & & & \multicolumn{4}{|c|}{$\left(\lambda_{j}\right)$} \\
\hline & \multicolumn{2}{|c|}{0.1526} & \multicolumn{2}{|c|}{0.1411} & \multicolumn{2}{|c|}{0.1274} & \multicolumn{2}{|c|}{0.0747} & \multicolumn{2}{|c|}{0.0611} & \multicolumn{2}{|c|}{0.2126} & \multicolumn{2}{|c|}{0.0832} & \multicolumn{2}{|c|}{0.0653} & \multicolumn{2}{|c|}{0.0821} \\
\hline SO & 0.000 & 0.389 & 0.000 & 0.000 & 1.000 & 0.611 & 0.877 & 0.955 & 0.123 & 0.046 & 0.009 & 0.052 & 0.991 & 0.948 & 0.893 & 0.969 & 0.107 & 0.031 \\
\hline ST & 0.187 & 0.052 & 0.678 & 0.896 & 0.135 & 0.052 & 0.375 & 0.500 & 0.625 & 0.500 & 0.006 & 0.024 & 0.994 & 0.976 & 0.710 & 0.500 & 0.290 & 0.500 \\
\hline WO & 0.009 & 0.022 & 0.496 & 0.320 & 0.496 & 0.658 & 0.765 & 0.958 & 0.235 & 0.042 & 0.270 & 0.024 & 0.730 & 0.976 & 0.218 & 0.948 & 0.782 & 0.052 \\
\hline WT & 0.082 & 0.017 & 0.788 & 0.492 & 0.129 & 0.492 & 1.000 & 0.968 & 0.000 & 0.032 & 0.009 & 0.024 & 0.991 & 0.976 & 0.880 & 0.991 & 0.120 & 0.009 \\
\hline$\left(e_{j}\right)$ & 0.4838 & 0.5323 & 0.7291 & 0.7799 & 0.8585 & 0.7694 & 0.9775 & 0.9610 & 0.5062 & 0.6421 & 0.9507 & 0.2677 & 0.9999 & 0.9943 & 0.9769 & 0.9274 & 0.4143 & 0.7689 \\
\hline$\left(V I_{j}\right)$ & 0.34709 & 0.21213 & 0.16847 & 0.09228 & 0.07942 & 0.08730 & 0.00740 & 0.00865 & 0.13296 & 0.06499 & 0.04617 & 0.46268 & 0.00002 & 0.00141 & 0.00665 & 0.01409 & 0.21191 & 0.05638 \\
\hline
\end{tabular}

Table 8 
Ranking of $S T$ strategies with application of $\left(V I_{i}\right)$ on the normalized decision matrix (where $\left(V I_{j}\right)$ have been normalized as the weights of criteria) as the weight of criteria, regarding to the proposed grey WPM formula.

\begin{tabular}{|c|c|c|c|c|c|c|c|c|c|c|c|c|c|c|c|c|}
\hline \multirow[t]{3}{*}{$W_{j}$} & 0.19434 & 0.11877 & 0.09433 & 0.05167 & 0.04447 & 0.04888 & 0.02585 & 0.25906 & 0.00001 & 0.00079 & 0.00372 & 0.00789 & 0.11865 & 0.03157 & & \\
\hline & \multicolumn{2}{|c|}{$\mathrm{SO}_{1}$} & \multicolumn{2}{|c|}{$\mathrm{SO}_{2}$} & \multicolumn{2}{|c|}{$\mathrm{SO}_{3}$} & \multicolumn{2}{|c|}{$W O_{1}$} & \multicolumn{2}{|c|}{$W O_{2}$} & \multicolumn{2}{|c|}{$W T_{1}$} & \multicolumn{2}{|c|}{$W T_{2}$} & \multirow{2}{*}{$\left(P_{i}\right)$} & \multirow{2}{*}{ Rank } \\
\hline & $G_{i j}$ & $\overline{G_{i j}}$ & $G_{i j}$ & $\overline{G_{i j}}$ & $G_{i j}$ & $\overline{G_{i j}}$ & $\underline{G_{i j}}$ & $\overline{G_{i j}}$ & $\underline{G_{i j}}$ & $\overline{G_{i j}}$ & $G_{i j}$ & $\overline{G_{i j}}$ & $G_{i j}$ & $\overline{G_{i j}}$ & & \\
\hline$S T_{1}$ & 0.500 & 0.600 & 0.500 & 0.500 & 0.333 & 0.375 & 0.546 & 0.526 & 1.000 & 0.667 & 0.000 & 0.375 & 0.143 & 0.375 & 6.9963 & 1 \\
\hline$S T_{2}$ & 0.500 & 0.400 & 0.500 & 0.500 & 0.667 & 0.625 & 0.455 & 0.474 & 0.000 & 0.333 & 1.000 & 0.625 & 0.857 & 0.625 & 6.9814 & 2 \\
\hline
\end{tabular}

Table 9

Ranking of $S T$ strategies with application of $\left(V I_{j}\right)$ as the weight of alternatives.

\begin{tabular}{ccccc}
\hline \multirow{2}{*}{ Strategies } & \multicolumn{2}{c}{$\left(V I_{i}\right)$} & $\left(P_{i}\right)$ & Score \\
\cline { 2 - 4 } & $\underline{G_{i j}}$ & $\overline{G_{i j}}$ & 6.9963 & 0.112291 \\
$S T_{1}$ & 0.00740 & 0.00865 & 6.9814 & 1.381968 \\
\hline$T_{2}$ & 0.13296 & 0.06499 & 2 & 1 \\
\hline
\end{tabular}

Table 10

Grey value importance for each strategy

\begin{tabular}{|c|c|c|c|c|c|c|c|c|}
\hline \multicolumn{3}{|c|}{ SO } & \multicolumn{3}{|c|}{$W T$} & \multicolumn{3}{|c|}{$W O$} \\
\hline Strategies & $V I_{j}$ & GIV & Strategies & $V I_{j}$ & GIV & Strategies & $V I_{j}$ & GIV \\
\hline $\mathrm{SO}_{1}$ & {$[0.34709,0.21213]$} & 359.877 & $W T_{1}$ & {$[0.00665,0.01409]$} & 28.974 & $W O_{1}$ & {$[0.04617,0.46268]$} & 10765544 \\
\hline $\mathrm{SO}_{2}$ & {$[0.16847,0.09228]$} & 61.449 & $W T_{2}$ & {$[0.21191,0.05638]$} & 1710.811 & $W_{2}$ & {$[0.00002,0.00141]$} & 2.334 \\
\hline $\mathrm{SO}_{3}$ & {$[0.07942,0.08730]$} & 186.506 & & & & & & \\
\hline
\end{tabular}

